This item was submitted to Loughborough's Research Repository by the author.

Items in Figshare are protected by copyright, with all rights reserved, unless otherwise indicated.

\title{
Generation of magnesium enriched water-in-oil-in-water food emulsions by stirred cell membrane emulsification
}

PLEASE CITE THE PUBLISHED VERSION

https://doi.org/10.1016/j.jfoodeng.2018.11.022

PUBLISHER

(C) Elsevier

VERSION

AM (Accepted Manuscript)

\section{PUBLISHER STATEMENT}

This paper was accepted for publication in the journal Journal of Food Engineering and the definitive published version is available at https://doi.org/10.1016/j.jfoodeng.2018.11.022.

\section{LICENCE}

CC BY-NC-ND 4.0

\section{REPOSITORY RECORD}

Pu, Xiaolu, Bettina Wolf, and Marijana Dragosavac. 2018. "Generation of Magnesium Enriched Water-in-oil-inwater Food Emulsions by Stirred Cell Membrane Emulsification”. figshare. https://hdl.handle.net/2134/36283. 


\section{Accepted Manuscript}

Generation of magnesium enriched water-in-oil-in-water food emulsions by stirred cell membrane emulsification

Xiaolu Pu, Bettina Wolf, Marijana Dragosavac

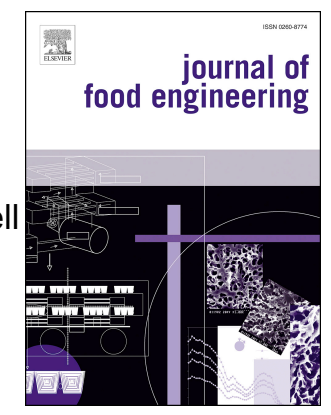

PII:

S0260-8774(18)30504-1

DOI: $\quad$ https://doi.org/10.1016/j.jfoodeng.2018.11.022

Reference: JFOE 9473

To appear in: Journal of Food Engineering

Received Date: 6 August 2018

Revised Date: 15 October 2018

Accepted Date: 26 November 2018

Please cite this article as: Pu, X., Wolf, B., Dragosavac, M., Generation of magnesium enriched water-inoil-in-water food emulsions by stirred cell membrane emulsification, Journal of Food Engineering (2018), doi: https://doi.org/10.1016/j.jfoodeng.2018.11.022.

This is a PDF file of an unedited manuscript that has been accepted for publication. As a service to our customers we are providing this early version of the manuscript. The manuscript will undergo copyediting, typesetting, and review of the resulting proof before it is published in its final form. Please note that during the production process errors may be discovered which could affect the content, and all legal disclaimers that apply to the journal pertain. 


\section{Highlights}

- PGPR was used to stabilise internal water droplet interface

- Starch and pea protein isolate were used to stabilise $w_{1} / o$ droplet interface

- Low energy membrane emulsification process generated stable $\mathrm{w}_{1} / \mathrm{o} / \mathrm{w}_{2}$ emulsions

- Variation of shear stress and injection rate produced drops between 35 and $320 \mu \mathrm{m}$

- Complex food emulsifiers delayed release of $\mathrm{Mg}^{2+}$ ions for up to 2 weeks

\section{Abstract}

This study has for the first time shown that complex food emulsifiers such as starch and protein can be applied to produce stable w/o/w emulsions with the membrane emulsification technology. Using a microporous metal membrane with a $20 \mu \mathrm{m}$ pore size, $2 \%$ of polyoxyethylene (20) sorbitan monolaurate (Tween 20 ), $4 \%$ of octenyl succinic anhydride (OSA) starch or $1.5 \%$ of pea protein isolate (PPI) in the external water phase respectively was the minimum concentration necessary to stabilise the $w / o / w$ droplets. Uniform with a span as low as 0.45 and for at least 13-day stable w/o/w 
emulsions of droplets between 35 and $320 \mu \mathrm{m}$ were obtained. The release of a magnesium tracer from the internal water phase of xanthan gum-thickened w/o/w emulsions, when OSA starch and PPI were used, was found to be limited to around 3\% after 13-day storage. However, w/o/w emulsions stabilised with Tween 20 were less stable with magnesium showing a release of $27 \%$ on day 13.

Keywords: membrane emulsification; w/o/w emulsion; food; OSA starch; pea protein; delayed magnesium release.

\section{Introduction}

Water-in-oil-in-water (w/o/w) emulsions are aqueous emulsions where the included oil droplet phase contains small water droplets in a water-in-oil emulsion. Such emulsion microstructure offers the opportunity to entrap in a food systems materials for targeted release in the internal aqueous phase, for example, micronutrients such as metal supplements, flavours and vitamins during consumption (Herzi and Essafi, 2018, Manickam et al., 2018). The release profiles of those components will depend on the oils and surfactants used as well as the droplet size of the w/o/w emulsion (Leadi Cole and L. Whateley, 1997, Oppermann et al., 2018, Schuch et al., 2013, Schuch et al., 2014). Lower encapsulation efficiency of the inner water phase in w/o/w emulsions stabilised with polyglycerol polyricinoleate (PGPR) and egg yolk powder were found to correlate with smaller double emulsion droplet size independent of two emulsification methods (Schuch et al., 2014). On the contrary, (Oppermann et al., 2018)) showed that greater encapsulation efficiency of the inner water phase in w/o/w emulsions was correlated to smaller double emulsion droplet size. Tween 20, sodium caseinate and Whey protein isolate were used as stabilizers of the external water phase. Consequently, it is appropriate to seek a tool to control the droplet size of $\mathrm{w} / \mathrm{o} / \mathrm{w}$ emulsions independent of the hydrophilic emulsifier type and to investigate the impact of the hydrophilic emulsifier alone on encapsulation efficiency. 
w/o/w emulsions are usually manufactured using a conventional two-step emulsification method based on high-pressure or high shear. However, these conventional methods rely on high energy input to disrupt the dispersed phase and form droplets (Schubert et al., 2003). The mechanical stress during processing tends to disrupt the emulsion droplets leading to a reduction in the encapsulation efficiency of the w/o/w emulsions (Kim et al., 2017). In contrast to this top-down processing approach, bottom-up processing technologies such as membrane emulsification and microchannel emulsification have been described in the literature as ways of obtaining a controllable droplet size while processing at much lower mechanical stress input (Joscelyne and Tragardh, 2000, Schröder et al., 1998, Schubert and Ax, 2003, Spyropoulos et al., 2014, Walstra and Smulders, 1998). Others often cited the advantages of bottom-up or mild emulsification processes to include increased energy efficiency as less energy is lost as frictional energy (Walstra, 1993) and prevention of degradation or loss of functionality of heat and shear sensitive ingredients used to stabilise the emulsions, for example starch and protein (Van Der Graaf et al., 2005). In this research membrane emulsification, specifically stirred cell membrane emulsification (Kosvintsev et al., 2005), was investigated as a process to generate similarly sized w/o/w emulsions of narrow droplet size distribution stabilised with different food emulsifiers.

PGPR, oil soluble surfactant, is commonly used in the oil phase of $w_{1} / o / w_{2}$ emulsions to stabilize the internal water phase $\left(w_{1}\right)$ via top-down processing (Chen et al., 2018, Silva et al., 2018). The primary emulsion $\left(w_{1} / 0\right)$ is then applied to further top-down or alternatively bottom-up processing to create the final w/o/w emulsion where water soluble surfactant (most commonly Tween 20) must be present in the outer water phase $\left(w_{2}\right)$. Another group recently reported on Tween 20 applied in the external aqueous emulsion phase to successfully stabilise w/o/w emulsions with encapsulated garlic extract via stirred cell membrane emulsification (Ilić et al., 2017, Nikolovski et al., 2018). Tween 20 is a small molecular weight surfactant with higher mobility compared to the macromolecules octenyl succinic anhydride starch (OSA) and pea protein isolate (PPI). OSA starch is native starch, often of the waxy type, 
i.e., majorly consisting of amylopectin, that has been chemically modified to contain the anionic and nonpolar group - octenyl succinic anhydride. PPI mainly contains two globular proteins, legumin and vicilin (O' Kane et al., 2005). Globular proteins are rigid molecules and rearrange at the interface slowly (Stauffer, 1999). The starch and protein sorb slower at the droplet surface compared to Tween 20 but develop a thick and viscoelastic layer and stabilise the droplets through steric and electrostatic repulsion (Bhosale and Singhal, 2006, Dickinson, 2010). Therefore, comparison of drop stabilisation and encapsulation/release properties of starch, protein and Tween 20 would be beneficial.

However, to the best of our knowledge, there are no publications on the use of complex food emulsifiers such as starches and proteins to stabilise w/o/w emulsions via membrane emulsification.

We were particularly interested in designing process conditions that would impart a comparable and narrow droplet size spectrum for both types of hydrophilic emulsifier, to then independently assess the release of magnesium encapsulated in the internal water phase. Magnesium was selected for convenient detection of release following previously published method (Bonnet et al., 2009). The emulsions, generated by stirred cell membrane emulsification, were thickened with the hydrophilic food hydrocolloid xanthan gum post emulsification to alleviate the impact of creaming on the results of the release measurement. Based on predictive modelling (Dragosavac et al., 2012), a formulation and processing protocol enabling the independent study of the impact of the choice of hydrophilic emulsifier on the release properties of a w/o/w emulsion, applicable to a broader choice of encapsulates than just magnesium, provided they will not alter the physico-chemical properties of the emulsion system, is introduced. 
All used materials were food grade and were used without modifications. To match the osmotic pressure $\mathrm{NaCl}$ (Fisher Scientific, Loughborough, UK) was used both in the internal $\left(\mathrm{w}_{1}\right)$ and the external water phase $\left(w_{2}\right)$ of $w_{1} / o / w_{2}$ emulsions. $\mathrm{NaCl}$ was selected as it enhances the adsorption of PGPR at the oil-water interface thus providing superior stability (Pawlik et al., 2010). $\mathrm{NaCl}$, within the internal water phase $\left(\mathrm{w}_{1}\right)$, was replaced with $\mathrm{MgCl}_{2} \cdot 6 \mathrm{H}_{2} \mathrm{O}$ (Sigma Aldrich, Dorset, UK) for easier and accurate detection of encapsulation efficiency or release. Internal water droplets $\left(w_{1}\right)$ were stabilised in the oil phase (sunflower oil, purchased from local supermarket) with PGPR (PGPR 90; DuPont Danisco, Kettering, UK). Tween 20 (Sigma Aldrich, Dorset, UK), octenyl succinic anhydride (OSA) starch ( $\mathrm{N}$-creamer 46, Univar, Widnes, UK) and pea protein isolate (PPI) (MyProtein, Northwich, UK) were applied as a hydrophilic emulsifier. Xanthan gum (CP Kelco, San Diego, USA) was used as a thickening agent. Deionized (DI) water, produced on site, was used throughout this study, and sodium azide (Sigma Aldrich, Dorset, UK) was added to all aqueous phases to suppress microbial spoilage. Acetone (Sigma Aldrich, Dorset, UK) was used as a solvent for a membrane wetting agent (Micropore Technologies Ltd., Redcar, UK). All concentrations are provided on a weight by weight basis, unless stated otherwise.

The external water phases $\left(w_{2}\right)$ were prepared by mixing the appropriate amount of hydrophilic emulsifier with $0.1 \mathrm{M} \mathrm{NaCl}$ solution. For investigating the impact of emulsifier concentration on stirred cell membrane emulsification $0.5 \%, 1 \%, 2 \%$ and $4 \%$ Tween $20 ; 2 \%$ and $4 \%$ OSA starch; and $0.5 \%, 1.5 \%, 3 \%$ and $6 \%$ PPI were applied.

For encapsulation efficiency and release measurement, $1600 \mathrm{ppm} \mathrm{Mg}^{2+}\left(\mathrm{MgCl}_{2} \cdot 6 \mathrm{H}_{2} \mathrm{O}\right.$, vacuum-dried overnight at $95^{\circ} \mathrm{C}$ to remove free moisture), was dissolved in water to constitute the internal aqueous phase $\left(w_{1}\right)$ of the $w_{1} / 0 / w_{2}$ emulsions instead of $0.1 \mathrm{M} \mathrm{NaCl}$. The outer water phase $\left(w_{2}\right)$ consisted of $0.5 \%$ xanthan gum and $2 \%$ Tween $20,4 \%$ OSA starch or $1.5 \%$ PPI. To maintain the 
osmotic pressure balance between two aqueous phases of the w/o/w emulsions, $\mathrm{Mg}^{2+}$ concentration was calculated according to Equation 1:

$$
\mathrm{C}_{\mathrm{Mg}^{2+}}+2 \mathrm{C}_{\mathrm{Cl}^{-}}=\mathrm{C}_{\mathrm{Na}^{+}}+\mathrm{C}_{\mathrm{Cl}^{-}}=2 \mathrm{C}_{\mathrm{NaCl}}=3 \mathrm{C}_{\mathrm{MgCl}_{2}}=0.2 \mathrm{M}
$$

122 where $\mathrm{C}_{\mathrm{Mg}^{2+}}, \mathrm{C}_{\mathrm{Cl}^{1}}, \mathrm{C}_{\mathrm{Na}^{+}}, \mathrm{C}_{\mathrm{NaCl}}$ and $\mathrm{C}_{\mathrm{MgCl}_{2}}$ are molar concentrations of $\mathrm{Mg}^{2+}, \mathrm{Cl}^{-}, \mathrm{Na}^{+}$ions, $\mathrm{NaCl}$ and $\mathrm{MgCl}_{2}$ present in $\mathrm{w}_{1}$. It was checked that the addition of $\mathrm{MgCl}_{2}$ to the $\mathrm{w} / \mathrm{o} / \mathrm{w}$ emulsions instead of $\mathrm{NaCl}$ had no influence on the microstructure and droplet size distribution. The oil phase contained 4\% PGPR and was prepared by stirring for at least $30 \mathrm{~min}$ on a magnetic stirrer at room temperature.

The $w_{1} / o$ emulsions, as the internal emulsion phase of the w/o/w emulsions, were produced by slow addition of internal water phase $\left(w_{1}\right)$ into the oil phase containing 4\% PGPR under high shear mixing (Ultra Turrax, model T25, IKA Works, Staufen, Germany) operating at $24000 \mathrm{rpm}$ for $5 \mathrm{~min}$. Emulsification was performed in an ice bath to avoid overheating. These process conditions have previously been reported to generate a droplet size of around $0.5 \mu \mathrm{m}$ (Vladisavljevic and Schubert, 2003). Final concentration of internal water phase $\left(w_{1}\right)$ within the oil phase was $40 \%$.

For the preparation of the $w_{1} / 0 / w_{2}$ emulsions stirred cell membrane emulsification was used. A hydrophilic nickel membrane with $4 \mathrm{~cm}$ diameter (Micropore Technologies Ltd., Redcar, UK), containing uniform straight through $20 \mu \mathrm{m}$ cylindrical pores with $200 \mu \mathrm{m}$ pore spacing, was used (see Figure A1 in the Appendix). Based on these two parameters, the porosity of the membrane (Dragosavac et al., 2008) was calculated to be $0.91 \%$. To increase the hydrophilicity of the membrane and to avoid the spreading of the dispersed phase (w/o emulsions) over the membrane 
Redcar, UK). For a set-up the membrane was placed in the base of the Dispersion Cell (Micropore Technologies Ltd., Redcar, UK) filled with continuous phase.

After preparation of the base, a cylinder glass cell (125 $\mathrm{cm}^{3}$ volume) was fitted over the membrane and filled with continuous phase (outer water phase $\left(w_{2}\right)$ ). A two-blade paddle stirrer, driven by a 24V DC motor and power supply (INSTEK Model PR 3060, UK), was fixed on the top of the cell. Maximum shear stress was controlled by rotational speed and ranged between 200 and $1500 \mathrm{rpm}$ corresponding to a maximum shear stress at the membrane surface between 1 and 51 Pa depending on a continuous phase used. The dispersion phases (primary $\mathrm{w}_{1} / \mathrm{o}$ emulsions) were injected through the microporous membrane surface using a syringe pump (AL-1000, World Precision Instrument, Hitchin, UK) fitted with a glass syringe of $29 \mathrm{~mm}$ inner diameter at constant injection rate in the range of 1 to $15 \mathrm{ml} \mathrm{min}{ }^{-1}$ corresponding to a transmembrane flux between 70 and $1150 \mathrm{~L} \mathrm{~h}^{-1} \mathrm{~m}^{-2}$. The experiments were continued until the dispersed phase volume fraction reached 10 or 30 vol.\%. Once the desired amount of the $\mathrm{w}_{1} / \mathrm{o}$ emulsion had passed through the membrane, the pump and the stirrer were switched off followed by transferring the w/o/w emulsion into a glass beaker $(100 \mathrm{ml}$ of w/o/w emulsion was prepared). Finally, $1 \mathrm{ml}$ aqueous sodium azide solution was added to w/o/w emulsions to obtain a final sodium azide concentration of $0.02 \%$ to prevent microbial spoilage. The beaker was then covered with cling film and stored at room temperature $\left(21 \pm 5^{\circ} \mathrm{C}\right)$ until further analysis.

After each use, the membrane was cleaned for 1 min with detergent solution in an ultrasonic bath followed by cleaning with acetone and DI water before drying using compressed air. 
their microstructure stability and encapsulation or release properties. Parameter settings are evident from the presentation of the results.

To predict the droplet diameter $(x)$ produced with the Dispersion Cell, a conventional shear force model (Kosvintsev et al., 2005) based on the balance between the capillary force (function of equilibrium interfacial tension $(\gamma)$ and pore size $\left(r_{p}\right)$ ) and the drag force (function of a maximum shear stress $\left(\tau_{\max }\right)$ and the droplet size $\left.(x)\right)$ acting on a strongly deformed droplet at a single membrane pore was applied. The droplet diameter can be estimated according to Equation 2.

$$
x=\frac{\sqrt{18 \tau_{\max }{ }^{2} r_{p}{ }^{2}+2 \sqrt{81 \tau_{\max }{ }^{4} r_{p}^{4}+4 r_{p}{ }^{2} \tau_{\max }{ }^{2} \gamma^{2}}}}{3 \tau_{\max }}
$$

Thus, to calculate the predicted droplet diameter, the interfacial tension between the $w_{1} / o$ phase and $w_{2}$ phases, the viscosity and the density of $w_{2}$ were measured as follows. All samples for these analyses were prepared in triplicate and analysed once.

Equilibrium interfacial tension $(\gamma)$ data at the interface between all the external aqueous emulsion phases and the $\mathrm{w}_{1} / \mathrm{o}$ emulsion was measured with a force tensiometer (DB2KS, White Electric Instrument, Malvern, UK) using the Du Nouy ring method at room temperature $\left(21 \pm 5{ }^{\circ} \mathrm{C}\right)$. The viscosity $\left(20^{\circ} \mathrm{C}\right)$ of all the external aqueous emulsion phases was measured using a rotational rheometer (MCR 301, Anton Paar, Graz, Austria) fitted with a concentric cylinder double gap geometry (DG26.7/T200). Shear rate was stepped up at 5 points/decade between 0.1 and $1000 \mathrm{~s}^{-1}$ and a total number of 21 points were acquired every $5 \mathrm{~s}$. The density of external aqueous emulsion phases was measured using a density meter (DMA 5000, Anton Paar, Graz, Austria). 


\subsection{Analysis of emulsion characteristics}

187 The visual microstructure appearance and droplet size distribution of the produced emulsions were analysed up to 13 days after processing (immediately after production; on day 1, 2, 6 and 13) to gain insight into their microstructure stability.

The microstructure of the $\mathrm{w} / \mathrm{o} / \mathrm{w}$ emulsions was visualised using an epifluorescence microscope (L3201LED, GT Vision Ltd., Suffolk, UK) operated in bright field illumination mode. Slides were prepared by pipetting a few drops of the continuous phase $\left(w_{2}\right)$ first, to reduce the influence of the surface tension on drops, and then a few drops of emulsion onto a glass slide followed by carefully sliding over a glass cover slip. At least three randomly selected areas of each slide were imaged at a lower and a higher magnification ( $\mathrm{x} 4$ and $\mathrm{x} 20$ objective) and three slides were prepared for each emulsion.

The droplet size distributions were analysed with a laser diffraction particle size analyser (Malvern Mastersizer 2000, Malvern Panalytical Ltd, Malvern, UK). The Dispersion cell was filled with deionized water as the dispersing medium. Measurement set up and analysis was controlled by the instrument's software package. The refractive index of the dispersion medium (water) and the dispersed phase (oil) was set to 1.33 and 1.47, respectively. The absorption value of the dispersed phase was set to zero. Once the emulsion was dispersed in the water, three measurements were taken, and the raw data was fitted with a general model. Measurement was carried out in triplicate.

2.5 Preparation of xanthan gum thickened emulsions

To prevent creaming during encapsulation or release measurements, xanthan gum was added to the emulsion after manufacturing. $1 \%$ xanthan gum solution was prepared by dispersing the xanthan gum powder into water pre-heated to $80^{\circ} \mathrm{C}$, while mixing at $1500 \mathrm{rpm}$ with an overhead mixer 
209 (RW20 fitted with a 4-bladed propeller stirrer, IKA, Staufen, Germany) for $1 \mathrm{~h}$. The solution was left

210 overnight to cool down to room temperature $\left(21 \pm 5^{\circ} \mathrm{C}\right)$ and to reach complete hydration before use.

$21170 \mathrm{~g}$ of xanthan gum solution was added to $100 \mathrm{~g}$ of emulsion and mixed at $600 \mathrm{rpm}$ on a magnetic

212 stirrer for 30 min obtaining a final xanthan gum concentration in the external aqueous phase of the

$213 \mathrm{w} / \mathrm{o} / \mathrm{w}$ emulsions of $0.5 \%$. Using the particle sized analyser and microscope, it was confirmed that

214 the droplet size and their distribution of the w/o/w emulsions did not change due to these mixing

215 conditions.

216

$217 \quad 2.6 \quad$ Assessing magnesium $\left(\mathrm{Mg}^{2+}\right)$ encapsulation and release

218 An Atomic Absorption Spectrophotometer (Spectra AA-200 Varian, UK), operating at the wavelength of $285.2 \mathrm{~nm}$, was used to detect $\mathrm{Mg}^{2+}$ concentration during the encapsulation and release study. Standard calibration curves with the $\mathrm{Mg}^{2+}$ concentration as a function of the measurement signal (absorbance) for different $w_{2}$ solutions are shown in Figure A2 in the Appendix. The absorption obtained from the spectroscopy increased with increasing magnesium concentration. The relationships were linear and repeatable.

To assess $w_{2}$ for leakage of $w_{1}$ and magnesium into $w_{2}$, the concentration of magnesium in $w_{2}$ was calculated based on the standard calibration curve. Magnesium release percentage was calculated as follows (Bonnet et al. 2009):

where $C_{M g}$ is the magnesium concentration in $w_{2}$, which was calculated from the corresponding calibration curves, made for each release media used. $\varphi_{w_{2}}$ is the volume fraction of $w_{2}$ in final $\mathrm{w}_{1} / \mathrm{o} / \mathrm{w}_{2}$ emulsion (0.8), $\varphi_{w_{1}}$ is the volume fraction of $\mathrm{w}_{1}$ in $\mathrm{w}_{1} / \mathrm{o}$ emulsion (0.4) and $C_{t}$ is the total 
231

232

233

234

235

236

237

238

239

240

241

242

243

244

245

246

247

248

$\mathrm{Mg}^{2+}$ concentration initially added in the internal water phase (1600 ppm). From the amount of $\mathrm{Mg}^{2+}$ released in the $w_{2}$ phase immediately after production (Figure 5 ; day 0 ) it is also possible to estimate Magnesium encapsulation efficiency $(E E) E E(\%)=100-\left(C_{M g} / C_{t}\right) \cdot\left(1-\varphi_{w_{2}}\right) / \varphi_{w_{1}} \cdot \varphi_{w_{2}}$ (Dragosavac et al., 2012).

To prepare the samples for release analysis, a $\mathrm{w}_{1} / \mathrm{o} / \mathrm{w}_{2}$ emulsion was centrifuged for $30 \mathrm{~min}$ at 3500 rpm (Heraeus Labofuge 400R, Thermo Scientific, Germany). The bottom layer was then carefully taken out by pipette and centrifuged again at the same conditions to ensure that $w_{2}$ was void of oil droplets. Via microscopic observation and droplet size analysis of the creamed emulsion droplets it was verified that the chosen centrifugation conditions had not changed the droplet size distribution. All measurements were taken over 13 days at the same days as emulsion droplet appearance was checked.

3 Results and discussion

\subsection{Effect of emulsifier concentration}

The effect of the surfactant concentration (Tween 20, OSA starch and PPI) and maximum shear stress on the w/o/w emulsions droplet size and span have been jointly reported in Figure 1. Having in mind that the model used to predict the droplet size using the Eq. 1 does not take into consideration the injection rate, the experimental data are shown for the injection rate of $1 \mathrm{ml} \mathrm{min}{ }^{-1}$ corresponding to the lowest meaningful injection rate applicable in the experimental set-up. Increasing emulsifier concentration led to a decrease in droplet size for the larger molecular weight emulsifiers PPI and OSA starch, but not for Tween 20. At the same time, droplet size decreased considerably when the maximum shear stress was stepped up from a low level ( $1 \mathrm{~Pa}$ ) to a mid and high level (6 and $20 \mathrm{~Pa}$ ), where the droplet size was comparable. These findings were independent of 
emulsifier type. In the case of the Tween 20 stabilised w/o/w emulsions (Figure 1A), the increase in emulsifier concentration from $0.5 \%$ to $4 \%$ had little impact on the droplet size, as could be expected based on the much lower literature value for this emulsifier's CMC reported in Table 2. On the other hand, the increase in Tween 20 concentration led to an improvement in the span for the intermediate maximum shear stress ( $6 \mathrm{~Pa})$. This could be due to the presence of excess emulsifier molecules in the continuous emulsion phase protecting the formed droplets against coalescence. In literature, $2 \%$ Tween 20 is often reported for the production of uniform and stable w/o/w emulsions (Dragosavac et al., 2012, Pawlik and Norton, 2012, Pradhan et al., 2014), and was therefore chosen as a constant in the investigation of the other processing parameters on emulsion microstructure. For OSA starch stabilised w/o/w emulsions (Figure 1B), the droplet size decreased when increasing OSA starch concentration from $2 \%$ to $4 \%$. This was accompanied with a span reduction to 0.53 for maximum shear stress of $51 \mathrm{~Pa}$. Further increase in starch concentration did not allow the formation of uniformly sized w/o/w emulsions, potentially due to the associated large increase in external phase viscosity. Therefore 4\% OSA starch was used in further experiments. For PPI stabilised w/o/w emulsions (Figure 1C), a decrease in the droplet size was observed with increasing PPI concentration from $0.5 \%$ to $1.5 \%$. Once the PPI concentration was above $1.5 \%$, no further decrease of the droplet size, while span increased, was observed. Thus, 1.5\% PPI was selected further on.

It is worth noting that the Tween 20 stabilised w/o/w emulsions had a smaller droplet size and slightly better emulsion uniformity (lower span) compared to the OSA starch and PPI stabilised emulsions. This can be explained by the higher surface activity of this low molecular weight emulsifier, as reported in Table 2, and the faster adsorption rate at the interface compared to the complex emulsifiers starch and protein (Bos and Van Vliet, 2001, Kralova and Sjöblom, 2009). Nevertheless, values of span never exceeded 1 when complex food emulsifiers were used. 
Both injection rate $\left(1-15 \mathrm{ml} \mathrm{min}^{-1}\right)$ and maximum shear stress (1-51 Pa) have been proven in literature to influence the mean droplet size and uniformity of w/o/w emulsions. Therefore, their joint influence was studied experimentally within the Dispersion cell. Concentration of emulsifiers was optimised and $2 \%$ Tween $20,4 \%$ OSA starch and $1.5 \%$ PPI was used to evaluate the maximum shear stress and injection rate influence. Produced emulsions showed the characteristic appearance of a w/o/w emulsion, namely dark appearance of the dispersed droplets. For illustration, one representative image of one emulsion each stabilised with Tween 20, OSA starch and PPI at the lowest and the highest maximum shear stress is shown in Figure 2.

Mean droplet size and span of the emulsions are presented in Figure 3 along with the model predictions for droplet size (Equation 1). The experimental droplet sizes were larger than the predicted data but followed the same decreasing trend with increasing maximum shear stress. As expected, experimental data was closest to the model prediction at the lowest injection rate of $1 \mathrm{ml}$ $\min ^{-1}$, and findings agree with literature (Dragosavac et al., 2012, Holdich et al., 2010, Vladisavljevic and Schubert, 2003).

When $2 \%$ Tween 20 was used as emulsifier, drops between 50 and $250 \mu \mathrm{m}$ were produced with a span below 0.7. At the low maximum shear stress ( $1 \mathrm{~Pa}), \mathrm{d}_{4,3}$ was larger than $200 \mu \mathrm{m}$, which is larger than the spacing between the pores. This could mean that the newly formed emulsion droplets built up at the membrane surface rather than immediately detached. Possibly, the small shear force applied with the paddle led to the formation of a droplet layer on the membrane surface, which then slowly dispersed into the bulk (Pawlik and Norton, 2012). Besides, it could be that not all of the membrane pores were used to produce droplets during emulsification, providing more space for droplets to grow on the membrane (Vladisavljevic and Schubert, 2002). When the lowest injection rate of $1 \mathrm{ml} \mathrm{min}{ }^{-1}$ was applied, uniform emulsion droplets with a span between 0.4 and 0.6 could be 
obtained. This also suggests that not all membrane pores were active. If all membrane pores were active to produce droplets, two neighbouring droplets would limit the droplet growth to interpore distance leading to a lower span due to the additional push off force (Kosvintsev et al. 2005). The lowest span for the Tween 20 stabilised system was 0.49 and recorded for $1 \mathrm{ml} \mathrm{min}^{-1}$ injection rate and $10 \mathrm{~Pa}$ maximum shear stress. The highest span of approximately 0.65 was found when the highest injection rate of $15 \mathrm{ml} \mathrm{min}{ }^{-1}$ and the extreme cases of the low (1 Pa) and high (20 Pa) end of the shear stress range was applied, which suggests fewer uniform droplets. This could be due to some large droplets being broken up by the paddle stirrer at the high maximum shear stress and droplets creaming at the low maximum shear stress or the highest injection rate (Dragosavac et al., 2012, Thompson et al., 2011).

When PPI was used to stabilise the w/o/w emulsions (Figure 3B) drops between 300 and $60 \mu \mathrm{m}$ were produced with spans below 0.85 . For the OSA starch as emulsifier (Figure 3C) drops between 350 and $65 \mu \mathrm{m}$ were produced with spans below 1 . The viscosity of the OSA starch solution was roughly $10 \mathrm{x}$ greater compared to the viscosity of the Tween and PPI solutions. Therefore, the greater span and larger droplet size of the emulsions stabilised with starch can be explained with the lower diffusivity of the molecules and longer time for drop stabilisation leading eventually to coalescence. As found for the Tween 20 stabilised system, when the lowest injection rate of $1 \mathrm{ml} \mathrm{min}^{-1}$ was applied, narrow droplet size distributions were generally produced with spans around 0.6 for the OSA starch and PPI stabilised systems. The lowest span for the OSA starch stabilised system was 0.4 when processed at

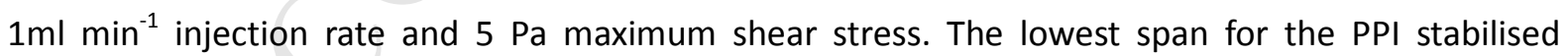
emulsions was 0.4 when processed at $10 \mathrm{ml} \mathrm{min}^{-1}$ injection rate and 1 Pa maximum shear stress.

The predicted droplet diameter decreased with increasing maximum shear stress for all emulsifiers (model line within Figure 3). As expected based on the interfacial tension values (see Table 2), the smallest droplet diameter was predicted for the Tween 20 (Figure 3A) stabilised emulsion, followed 
by PPI (Figure 3B) and then OSA starch (Figure 3C) stabilised systems, at all maximum shear stress

327

328

329

330

331

332

333

334

335

values. The maximum shear stress range was extended to higher values for the OSA starch stabilised w/o/w emulsion due to its around tenfold higher viscosity of the continuous emulsion phase compared to the other two systems (see Table 2). The maximum shear stress range of the predicted droplet diameter curve for the Tween 20 and the PPI stabilised systems were very similar.

A relatively high maximum shear stress in the present set-up (14-51Pa) combined with a low injection rate (i.e. $1 \mathrm{ml} \mathrm{min}{ }^{-1}$ ) yielded w/o/w emulsions for all three emulsifiers with comparable droplet size of around 60-70 $\mu \mathrm{m}$. As our intention for the $\mathrm{Mg}^{2+}$ encapsulation/release tests was to investigate the influence of emulsifier independently of droplet size (to keep the surface area for the release constant) droplets with a diameter of roughly $60 \mu \mathrm{m}$ were produced according to the conditions from Figure 3.

\subsection{Mid-term microstructure stability of the $w / 0 / w$ emulsions}

The coalescence stability of the w/o/w emulsions stabilised with $2 \%$ Tween $20,4 \%$ OSA starch and

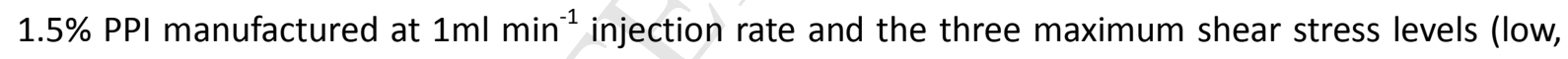
mid and high) was investigated for up to 13 days after processing.

Figure 4 shows the corresponding droplet size distributions and micrographs. For each emulsion, the droplet size distributions showed no difference over 13 days, which suggests these w/o/w emulsions were stable against coalescence independent of emulsifier type and sample age. Although all w/o/w emulsions creamed by visual observation, the micrographs show that there was no apparent change in microstructure and no emptying out for any of the emulsions over the 13 day period of observation. As it can be seen from Figure 4, even on day 13, the emulsion droplets had a dark appearance, which demonstrates that there was little or no loss of the inner water droplets from the oil droplets of the $w / o / w$ emulsions. 
Magnesium release was tracked over a period of 13 days to explore encapsulation efficiency of magnesium or the diffusion of the internal water phase $\left(w_{1}\right)$ to the external water phase $\left(w_{2}\right)$ of the $w_{1} / o / w_{2}$ emulsions. These emulsions had xanthan gum added post emulsification to eliminate the impact of creaming on the release data. According to section 3.2, similarly sized uniform droplets (roughly $60 \mu \mathrm{m}$ diameter), characterised by a low span, independent of emulsifier type were obtained when a low injection rate $\left(1 \mathrm{ml} \mathrm{min}^{-1}\right)$ was combined with the maximum shear stress of 14 , 16 and 36 Pa for Tween 20, PPI and OSA starch (see Figure 3). For production of w/o/w emulsions for the release measurement sodium chloride was substituted for magnesium as a more convenient marker molecule (see section 2.6). To maximise the observation window, the volume fraction of $\mathrm{w}_{1} / \mathrm{o}$ in $\mathrm{w} / \mathrm{o} / \mathrm{w}$ emulsions was increased from 10 vol.\% to 30 vol.\%. So, initially it was ascertained through microscopic inspection and acquisition of droplet size distribution data that these two formulation changes had no impact on the microstructure of the w/o/w emulsions. There was no apparent change in the microstructure of the w/o/w emulsions when using $\mathrm{Mg}^{2+}$ instead of $\mathrm{NaCl}$ in $\mathrm{w}_{1}$ compared to the respective microstructure shown in Figure 3 on the day of emulsion processing and on day 13 (micrographs omitted for sake of brevity).

Figure 5 shows the release of magnesium from $w_{1}$ into $w_{2}$ of the xanthan gum thickened w/o/w emulsions over 13 days. It has been widely reported that an increase in the viscosity of aqueous phases in w/o/w emulsions by the addition of thickening and gelling agents leads to an improvement in the encapsulation efficiency of w/o/w emulsions (Kim et al., 2017, Oppermann et al., 2018). Although viscosity change induced by xanthan gum was expected to play a significant role on the encapsulation efficiency, there were differences found in the released amount of magnesium from all xanthan gum added w/o/w emulsions depending on emulsifier type. Encapsulation efficiency 
immediately after production was $100 \%$ for the OSA starch and PPI stabilised w/o/w emulsions. The OSA starch and PPI stabilised w/o/w emulsions showed some release only between day 3 and day 6 after emulsion preparation. Approximately $1 \%$ of magnesium were detected in $w_{2}$ on day 6 . Release continued at a slow rate and reached roughly $3 \%$ on day 13 . So, these two types of emulsions appeared relatively stable against magnesium release from the encapsulated water phase, thus it is assumed that there was limited diffusion of $w_{1}$ into $w_{2}$ setting on only between 3 and 6 days after emulsion generation.

The Tween 20 stabilised w/o/w emulsion was less stable against magnesium release. 5\% magnesium release was noted on the day of emulsion processing meaning that encapsulation efficiency of $2 \%$ Tween was $95 \%$. This could be indicative of a rapid setting on of diffusion of $w_{1}$ into $w_{2}$, or loss of $w_{1}$ into $w_{2}$ during the emulsification process. Magnesium continuously leaked into the external water phase albeit at decreasing rate over time. Similar observations for Tween 20 stabilised w/o/w emulsions, but manufactured at a higher injection speed (about $5 \mathrm{ml} \mathrm{min}^{-1}$ ), so having a larger droplet size $\left(d_{3,2}=107 \mu \mathrm{m}\right)$, and encapsulating copper in $w_{1}$, have previously been reported (Dragosavac et al., 2012). In that case around $50 \%$ of the encapsulated copper was released and w/o/w drops appeared clear within 13 days of emulsion generation. In the current study, there was no apparent change in the droplet appearance of Tween 20 stabilised w/o/w emulsions after 13-day storage. However, a loss of $27 \%$ of internal water phase $\left(w_{1}\right)$ into $w_{2}$ by day 13 has been detected. Nevertheless, this loss might not be enough to visibly change the appearance of the droplets, but diffusion of $w_{1}$ into $w_{2}$ might still have occurred. Water and water soluble material transport in w/o/w emulsions can be explained either by a swelling-breakdown mechanism or diffusion and/ or permeation through the oil film (Cheng et al., 2007). Specifically, mechanisms behind diffusion and/ or permeation including an osmotic pressure gradient between two aqueous phases (Matsumoto et al., 1980), the thin lamellae of surfactant which partially form in the oil layer due to fluctuations in its thickness (Garti, 1997, Jager-Lezer et al., 1997), or reverse micelles in the oil phase (Sela et al., 1995) 
have previously been reported. Since the osmotic pressure was balanced in this study, water transport between two aqueous phases and release of magnesium might result from the thin lamellae of surfactant forming in the oil film and the PGPR micelles and/or Tween 20 reverse micelles in the oil phase.

403

\section{Conclusions}

405

406

407

408

409

410

411

This research has for the first time shown that complex food emulsifiers such as starch and protein can be applied to produce stable w/o/w emulsions with the technology of stirred cell membrane emulsification. One should consider though that stabilisation with a low molecular surfactant such as Tween 20 would allow formation of slightly more uniform droplet size distributions (lower span) with a lower mean diameter. For the release of magnesium from the internal water phase to the external water phase, OSA starch and PPI stabilised w/o/w emulsions thickened by xanthan gum showed a better stability against release than Tween 20 stabilised ones. The results reported in this study enabled the production of uniformly sized w/o/w emulsions with similar average droplet diameters and high encapsulation efficiency using complex food emulsifiers. Immediately after production encapsulation efficiency for OSA starch and PPI was $100 \%$ while for Tween it was $97 \%$. Delayed release was obtained when complex food emulsifiers (starch and protein) were used with almost no release up to 2 days. After 13 days, the emulsions stabilised with Tween 20 had released almost $30 \%$ of $\mathrm{Mg}^{2+}$ and for those stabilised with starch and protein $\mathrm{Mg}^{2+}$ leakage was less than $4 \%$. This study has introduced a pathway, beneficial for food and pharmaceutical applications, to enhance the stability and encapsulation efficiency of $w / o / w$ emulsions based on the appropriate selection of the hydrophilic emulsifier. Low energy membrane emulsification process proved to be a worthy tool to control as desired, both the droplet size of w/o/w emulsions independent of the 
hydrophilic emulsifier. Future work will focus on incorporation of volatile flavours within the

emulsion matrix stabilised by complex food emulsifiers (PPI and starch).

Acknowledgement

XP acknowledges the scholarship from China Scholarship Council (CSC).

BAHTZ, J., GUNES, D. Z., SYRBE, A., MOSCA, N., FISCHER, P. \& WINDHAB, E. J. (2016). Quantification of spontaneous $\mathrm{w} / \mathrm{o}$ emulsification and its impact on the swelling kinetics of multiple $\mathrm{w} / \mathrm{o} / \mathrm{w}$ emulsions. Langmuir, 32, 5787-5795.

BAHTZ, J., GUNES, D. Z., SYRBE, A., MOSCA, N., FISCHER, P. \& WINDHAB, E. J. (2016). Quantification of spontaneous w/o emulsification and its impact on the swelling kinetics of multiple w/o/w emulsions. Langmuir, 32, 5787-5795.

BHOSALE, R. \& SINGHAL, R. (2006). Process optimization for the synthesis of octenyl succinyl derivative of waxy corn and amaranth starches. Carbohydrate Polymers, 66, 521-527.

BONNET, M., CANSELL, M., BERKAOUI, A., ROPERS, M. H., ANTON, M. \& LEAL-CALDERON, F. (2009). Release rate profiles of magnesium from multiple W/O/W emulsions. Food Hydrocolloids, 23, 92-101.

BOS, M., A. \& VAN VLIET, T. (2001). Interfacial rheological properties of adsorbed protein layers and surfactants: a review. Advances in Colloid and Interface Science, 91, 437-471.

CHEN, X., MCCLEMENTS, D. J., WANG, J., ZOU, L., DENG, S., LIU, W., YAN, C., ZHU, Y., CHENG, C. \& LIU, C. (2018). Coencapsulation of (-)-Epigallocatechin-3-gallate and Quercetin in ParticleStabilized W/O/W Emulsion Gels: Controlled Release and Bioaccessibility. Journal of Agricultural and Food Chemistry.

CHENG, J., CHEN, J.-F., ZHAO, M., LUO, Q., WEN, L.-X. \& PAPADOPOULOS, K. D. (2007). Transport of ions through the oil phase of $\mathrm{W}-1 / \mathrm{O} / \mathrm{W}-2$ double emulsions. Journal of Colloid and Interface Science, 305, 175-182.

COTTRELL, T. \& VAN PEIJ, J. (2015). Sorbitan esters and polysorbates. In: NORN, V. (ed.) Emulsifiers in food technology. West Sussex, UK: Wiley Blackwell.

DICKINSON, E. (2010). Flocculation of protein-stabilized oil-in-water emulsions. Colloids Surf B Biointerfaces, 81, 130-40.

DRAGOSAVAC, M. M., HOLDICH, R. G., VLADISAVLJEVIĆ, G. T. \& SOVIL, M. N. (2012). Stirred cell membrane emulsification for multiple emulsions containing unrefined pumpkin seed oil with uniform droplet size. Journal of Membrane Science, 392-393, 122-129.

DRAGOSAVAC, M. M., SOVILJ, M. N., KOSVINTSEV, S. R., HOLDICH, R. G. \& VLADISAVLJEVIĆ, G. T. (2008). Controlled production of oil-in-water emulsions containing unrefined pumpkin seed oil using stirred cell membrane emulsification. Journal of Membrane Science, 322, 178-188. 
GARTI, N. (1997). Progress in stabilization and transport phenomana of double emulsions in food applications. Lebensm.-Wiss.u.-Technol, 30, 222-235.

GHARSALLAOUI, A., CASES, E., CHAMBIN, O. \& SAUREL, R. (2009). Interfacial and emulsifying characteristics of acid-treated pea protein. Food Biophysics, 4, 273-280.

HERZI, S. \& ESSAFI, W. (2018). Different magnesium release profiles from W/O/W emulsions based on crystallized oils. Journal of Colloid and Interface Science, 509, 178-188.

HOLDICH, R. G., DRAGOSAVAC, M. M., VLADISAVLJEVIĆ, G. T. \& KOSVINTSEV, S. R. (2010). Membrane emulsification with oscillating and stationary membranes. Industrial \& Engineering Chemistry Research, 49, 3810-3817.

ILIĆ, J. D., NIKOLOVSKI, B. G., PETROVIĆ, L. B., KOJIĆ, P. S., LONČAREVIĆ, I. S. \& PETROVIĆ, J. S. (2017). The garlic (A.sativum L.) extracts food grade W1/O/W2 emulsions prepared by homogenization and stirred cell membrane emulsification. Journal of Food Engineering, 205, 1-11.

JAGER-LEZER, N., TERRISSE, I., BRUNEAU, F., TOKGOZ, S., FERREIRA, L., CLAUSSE, D., SEILLER, M. \& GROSSIORD, J. L. (1997). Influence of lipophilic surfactant on the release kinetics of watersoluble molecules entrapped in a W/O/W multiple emulsion. Journal of Controlled Release, 45, 1-13.

JOSCELYNE, S. M. \& TRAGARDH, G. (2000). Membrane emulsification - a literature review. Journal of Membrane Science, 169, 107-117.

KASPRZAK, M. M., MACNAUGHTAN, W., HARDING, S., WILDE, P. \& WOLF, B. (2018). Stabilisation of oil-in-water emulsions with non-chemical modified gelatinised starch. Food Hydrocolloids, 81, 409-418.

KIM, Y.-L., MUN, S., RHO, S.-J., DO, H. V. \& KIM, Y.-R. (2017). "Influence of physicochemical properties of enzymatically modified starch gel on the encapsulation efficiency of W/O/W emulsion containing $\mathrm{NaCl}$ ". Food and Bioprocess Technology, 10, 77-88.

KOSVINTSEV, S. R., GASPARINI, G., HOLDICH, R. G., CUMMING, I. W. \& STILLWELL, M. T. (2005). Liquid-liquid membrane dispersion in a stirred cell with and without controlled shear. Industrial \& Engineering Chemistry Research, 44, 9323-9330.

KRALOVA, I. \& SJ BLOM, J. (2009). Surfactants used in food industry: a review. Journal of Dispersion Science and Technology, 30, 1363-1383.

KRSTONOŠIĆ, V., DOKIĆ, L. \& MILANOVIĆ, J. (2011). Micellar properties of OSA starch and interaction with xanthan gum in aqueous solution. Food Hydrocolloids, 25, 361-367.

LEADI COLE, M. \& L. WHATELEY, T. (1997). Release rate profiles of theophylline and insulin from stable multiple w/o/w emulsions. Journal of Controlled Release, 49, 51-58.

MANICKAM, S., MUTHOOSAMY, K. \& RAVIADARAN, R. (2018). Simple and Multiple Emulsions Emphasizing on Industrial Applications and Stability Assessment. Food Process Engineering and Quality Assurance. Apple Academic Press.

MATSUMOTO, S., INOUE, T., KOHDA, M. \& IKURA, K. (1980). Water permeability of oil layers in $\mathrm{W} / \mathrm{O} / \mathrm{W}$ emulsions under osmotic pressure gradients. Journal of Colloid and Interface Science, 77, 555-563.

NIKOLOVSKI, B. G., BAJAC, J. D., MARTINOVIC, F. L. \& BOGUNOVIĆ, N. (2018). Optimizing stirred cell membrane emulsification process for making a food-grade multiple emulsion. Chemical Papers, 72, 533-542.

O' KANE, F. E., VEREIJKEN, J. M., GRUPPEN, H. \& VAN BOEKEL, M. (2005). Gelation behavior of protein isolates extraded from 5 cultivars of Pisum sativum L. Journal of Food Science, 70, C132-C137.

OBRADOVIĆ, S. \& POŠA, M. (2017). The influence of the structure of selected Brij and Tween homologues on the thermodynamic stability of their binary mixed micelles. The Journal of Chemical Thermodynamics, 110, 41-50. 
OPPERMANN, A. K. L., NOPPERS, J. M. E., STIEGER, M. \& SCHOLTEN, E. (2018). Effect of outer water phase composition on oil droplet size and yield of (w1/o/w2) double emulsions. Food Research International, 107, 148-157.

PAWLIK, A., COX, P. W. \& NORTON, I. T. (2010). Food grade duplex emulsions designed and stabilised with different osmotic pressures. J Colloid Interface Sci, 352, 59-67.

PAWLIK, A. K. \& NORTON, I. T. (2012). Encapsulation stability of duplex emulsions prepared with SPG cross-flow membrane, SPG rotating membrane and rotor-stator techniques-A comparison. Journal of Membrane Science, 415, 459-468.

PRADHAN, R., KIM, Y.-I., JEONG, J.-H., CHOI, H.-G., YONG, C. S. \& KIM, J. O. (2014). Fabrication, Characterization and Pharmacokinetic Evaluation of Doxorubicin-Loaded Water-in-Oil-inWater Microemulsions Using a Membrane Emulsification Technique. Chemical and Pharmaceutical Bulletin, 62, 875-882.

SCHR DER, V., BEHREND, O. \& SCHUBERT, H. (1998). Effect of Dynamic Interfacial Tension on the Emulsification Process Using Microporous, Ceramic Membranes. Journal of Colloid and Interface Science, 202, 334-340.

SCHUBERT, H. \& AX, K. (2003). Engineering food emulsions. In: MCKENNA, B. M. (ed.) Texture in food, volume 1: semid-solid foods. 1st Edition ed. Boca Raton, FL, USA: CRC Press.

SCHUBERT, H., AX, K. \& BEHREND, O. (2003). Product engineering of dispersed systems. Trends in Food Science \& Technology, 14, 9-16.

SCHUCH, A., DEITERS, P., HENNE, J., K HLER, K. \& SCHUCHMANN, H. P. (2013). Production of W/O/W (water-in-oil-in-water) multiple emulsions: droplet breakup and release of water. Journal of Colloid and Interface Science, 402, 157-164.

SCHUCH, A., WRENGER, J. \& SCHUCHMANN, H. P. (2014). Production of W/O/W double emulsions. Part II: Influence of emulsification device on release of water by coalescence. Colloids and Surfaces A: Physicochemical and Engineering Aspects, 461, 344-351.

SELA, Y., MAGDASSI, S. \& GARTI, N. (1995). Release of markers from the inner water phase of $\mathrm{W} / \mathrm{O} / \mathrm{W}$ emulsions stabilized by silicone based polymeric surfactants. Journal of controlled release, 33, 1-12.

SHOGREN, R. L., VISWANATHAN, A., FELKER, F. \& GROSS, R. A. (2000). Distribution of octenyl succinate groups in octenyl succinic anhydride modified waxy maize starch. Starch - Stärke, 52, 196-204.

SILVA, W., TORRES-GATICA, M. F., OYARZUN-AMPUERO, F., SILVA-WEISS, A., ROBERT, P., COFRADES, S. \& GIM NEZ, B. (2018). Double emulsions as potential fat replacers with gallic acid and quercetin nanoemulsions in the aqueous phases. Food Chemistry, 253, 71-78.

SPYROPOULOS, F., LLOYD, D. M., HANCOCKS, R. D. \& PAWLIK, A. K. (2014). Advances in membrane emulsification. Part A: recent developments in processing aspects and microstructural design approaches. Journal of the Science of Food and Agriculture, 94, 613-627.

STAUFFER, C. E. (1999). Emulsifiers, St. Paul, Minnesota, Eagan Press.

THOMPSON, K. L., ARMES, S. P. \& YORK, D. W. (2011). Preparation of Pickering Emulsions and Colloidosomes with Relatively Narrow Size Distributions by Stirred Cell Membrane Emulsification. Langmuir, 27, 2357-2363.

USHIKUBO, F. Y. \& CUNHA, R. L. (2014). Stability mechanisms of liquid water-in-oil emulsions. Food Hydrocolloids, 34, 145-153.

VAN DER GRAAF, S., SCHRO N, C. G. P. H. \& BOOM, R. M. (2005). Preparation of double emulsions by membrane emulsification-a review. Journal of Membrane Science, 251, 7-15.

VLADISAVLJEVIC, G. T. \& SCHUBERT, H. (2002). Preparation and analysis of oil-in-water emulsions with a narrow droplet size distribution using Shirasu-porous-glass (SPG) membranes. Desalination, 144, 167-172. 
556 VLADISAVLJEVIC, G. T. \& SCHUBERT, H. (2003). Influence of process parameters on droplet size distribution in SPG membrane emulsification and stability of prepared emulsion droplets. Journal of Membrane Science, 225, 15-23.

WALSTRA, P. (1993). Principles of emulsion formation. Chemical Engineering Science, 48, 333-349.

WALSTRA, P. \& SMULDERS, P. E. A. (1998). Emulsion formation. In: BINKS, B. P. (ed.) Modern aspects of emulsion science. 1st Edition ed. Cambridge, UK: The Royal Society of Chemistry. 
564

565

566

567

568

569 Table 2: Physico
concentration.

570

571

572 
573 Table 1: Averaged interfacial tension, viscosity (at $10 \mathrm{~s}^{-1}$ ) and density data acquired at $20^{\circ} \mathrm{C}$

\begin{tabular}{llll}
\hline $\mathrm{w}_{2}$ & $\begin{array}{l}\text { interfacial tension at } \\
\mathrm{w}_{1} / \mathrm{o} \text { interface }(\mathrm{mN} / \mathrm{m})\end{array}$ & $\begin{array}{l}\text { viscosity } \\
(\mathrm{mPa} . \mathrm{s})\end{array}$ & density $\left(\mathrm{g} / \mathrm{cm}^{3}\right)$ \\
\hline $2 \%$ Tween 20 in $0.1 \mathrm{M} \mathrm{NaCl}$ & $5.9 \pm 0.4$ & $1.07 \pm 0.01$ & $1.0050 \pm 0.0000$ \\
$4 \%$ OSA starch in $0.1 \mathrm{M} \mathrm{NaCl}$ & $13.7 \pm 0.2$ & $11.57 \pm 0.12$ & $1.0173 \pm 0.0000$ \\
$1.5 \% \mathrm{PPI}$ in $0.1 \mathrm{M} \mathrm{NaCl}$ & $10.5 \pm 0.4$ & $1.26 \pm 0.05$ & $1.0065 \pm 0.0002$ \\
\hline
\end{tabular}

574

575

576 
Table 2: Physicochemical properties of emulsifiers used in this study. CMC: critical micelle concentration .

\begin{tabular}{|c|c|c|c|}
\hline Emulsifier & $\begin{array}{l}\text { Approxim } \\
\text { ate } \\
\text { molecular } \\
\text { weight } \\
\text { (g/mol) }\end{array}$ & $\begin{array}{l}\text { Approximate } \\
\text { CMC }\end{array}$ & Structural formula \\
\hline PGPR & $\begin{array}{l}3000 \\
\text { (Ushikubo } \\
\text { and } \\
\text { Cunha, } \\
\text { 2014) }\end{array}$ & $\begin{array}{l}1.8(\% \mathrm{w} / \mathrm{w}) \\
\text { at } 20^{\circ} \mathrm{C} \\
\text { (Bahtz et al., } \\
2016)\end{array}$ & $\begin{array}{l}\text { A) chemical structure of PGPR. } R \text { is a hydrogen, ricinoleic } \\
\text { acid or polyricinoleic acid. The average value of } n \text { is about } 3 \text {. } \\
\text { B) chemical structure of ricinoleic acid. (Ushikubo and } \\
\text { Cunha, 2014) }\end{array}$ \\
\hline Tween 20 & $\begin{array}{l}1228 \\
\text { (Obradovi } \\
\text { ć and } \\
\text { Poša, } \\
2017 \text { ) }\end{array}$ & $\begin{array}{l}0.07(\% \mathrm{w} / \mathrm{w}) \\
\text { at } 25^{\circ} \mathrm{C} \\
\text { (Cottrell and } \\
\text { Van Peij, } \\
2015)\end{array}$ & Dotted box notes the alkyl chain. (Obradović and Poša, 2017) \\
\hline $\begin{array}{l}\text { OSA } \\
\text { starch }\end{array}$ & $\begin{array}{l}470000 \\
\text { (Kasprzak } \\
\text { et al., } \\
\text { 2018) }\end{array}$ & $\begin{array}{l}0.05(\% \mathrm{w} / \mathrm{v}) \\
\text { at } 25^{\circ} \mathrm{C} \\
\text { (Krstonošić } \\
\text { et al., 2011) }\end{array}$ & (Shogren et al., 2000) \\
\hline PPI & $\begin{array}{l}\text { Main } \\
\text { compone } \\
\text { nts (O' } \\
\text { Kane et } \\
\text { al., 2005): } \\
\text { legumin, } \\
380000 \\
\text { g/mol; } \\
\text { vicilin, } \\
150000 \\
\text { g/mol. }\end{array}$ & $\begin{array}{l}0.04(\% \mathrm{w} / \mathrm{w}) \\
\text { at } 20^{\circ} \mathrm{C} \\
\text { (Gharsallaoui } \\
\text { et al., 2009) }\end{array}$ & - \\
\hline
\end{tabular}


581 
2 Figure 1: Effect of emulsifier concentration of A) Tween 20 B) OSA starch C) PPI to stabilise the w/o/w

3 emulsion assessed at three maximum shear stresses and at the injection rate of $1 \mathrm{ml} \mathrm{min} \mathrm{m}^{-1}$ on the droplet

4 size $\left(d_{4,3}\right)$ and span. Single experiments were carried out.

5 Figure 2: Micrographs of Tween 20, OSA starch or PPI stabilised w/o/w emulsions through stirrer cell membrane emulsification under different injection rates (1-15 $\left.\mathrm{ml} \mathrm{min}^{-1}\right)$ and $\left.\mathrm{A}\right)$ lowest (1 Pa) or B) highest

7 maximum shear stress (Tween 20: 20 Pa. OSA starch: $51 \mathrm{~Pa}$. PPI: $21 \mathrm{~Pa}$ ). The scale bar in each micrograph 8 is $300 \mu \mathrm{m}$.

9 Figure 3: Effect of maximum shear stress (1-51 Pa) and injection rate $\left(1-15 \mathrm{ml} \mathrm{min}^{-1}\right)$ on mean droplet 10 diameter $\left(\mathrm{d}_{4,3}\right)$ and span of $\mathrm{w} / \mathrm{o} / \mathrm{w}$ emulsions stabilised with A) $2 \%$ Tween $\left.20, \mathrm{~B}\right) 4 \%$ OSA starch or C) $1.5 \%$

11 PPI obtained experimentally and as predicted by the published model for comparison.

12 Figure 4: Droplet size distributions of w/o/w emulsions stabilised with A) 2\% Tween 20 B) 4\% OSA starch 13 or C) $1.5 \% \mathrm{PPI}$ at different maximum shear stress.

14 Days: $\square$ day 0 (production), $\square$ day 1 , 圆 day 2, 圈 day 6 , $\square$ day 13 . The scale bar in each micrograph is $15300 \mu \mathrm{m}$. 
20

A)

21
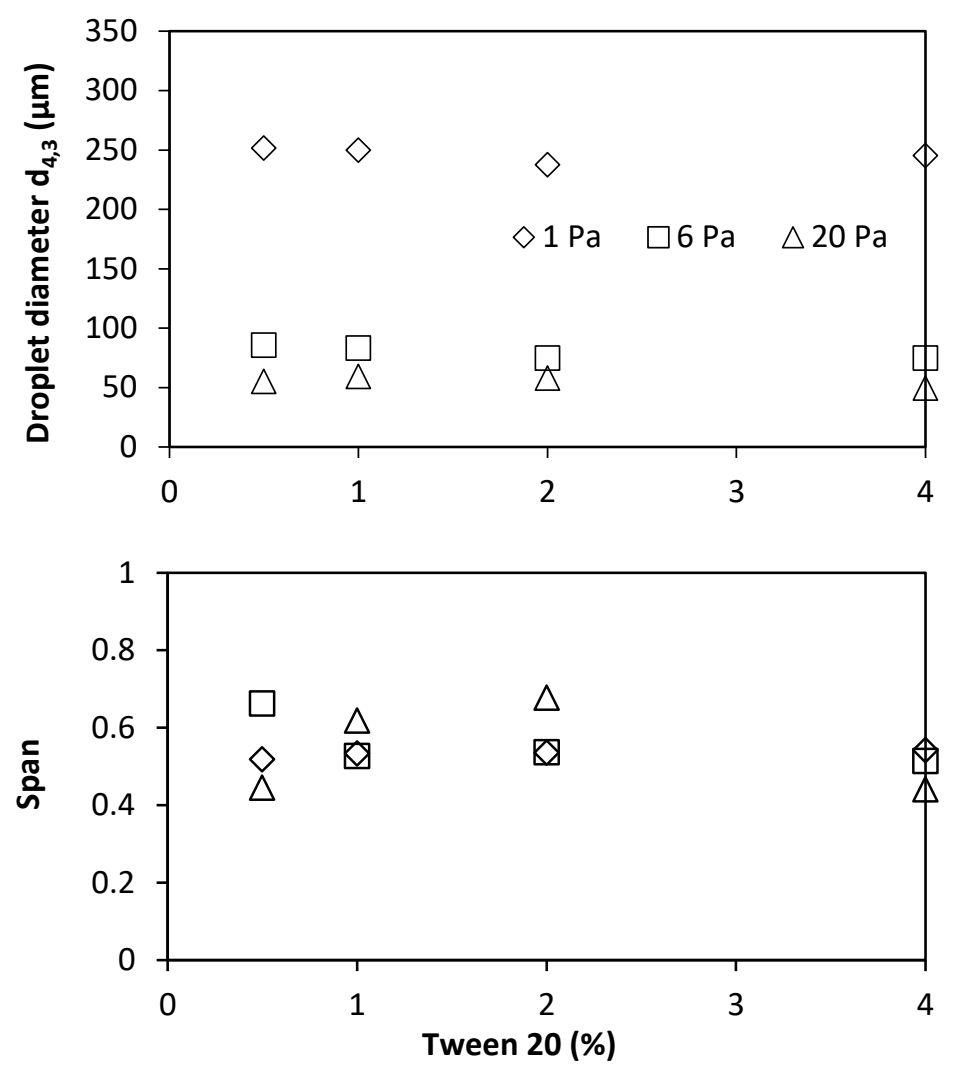

23

24

25

26

27

28

29

30

31

32

33

34

35

36

37

38

39

40

41

42

43

44

45

46 
$\begin{array}{ll}47 & \text { B) }\end{array}$

48
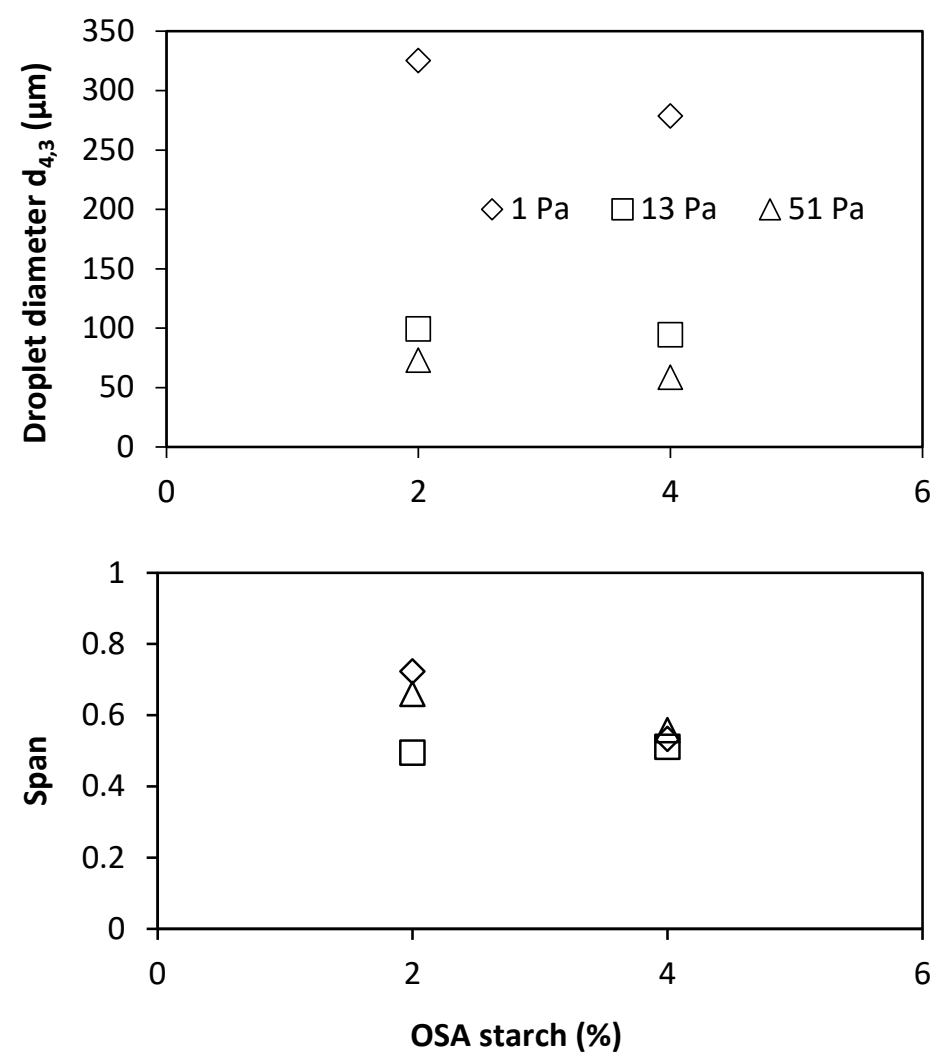

49

50 
51 C)

52
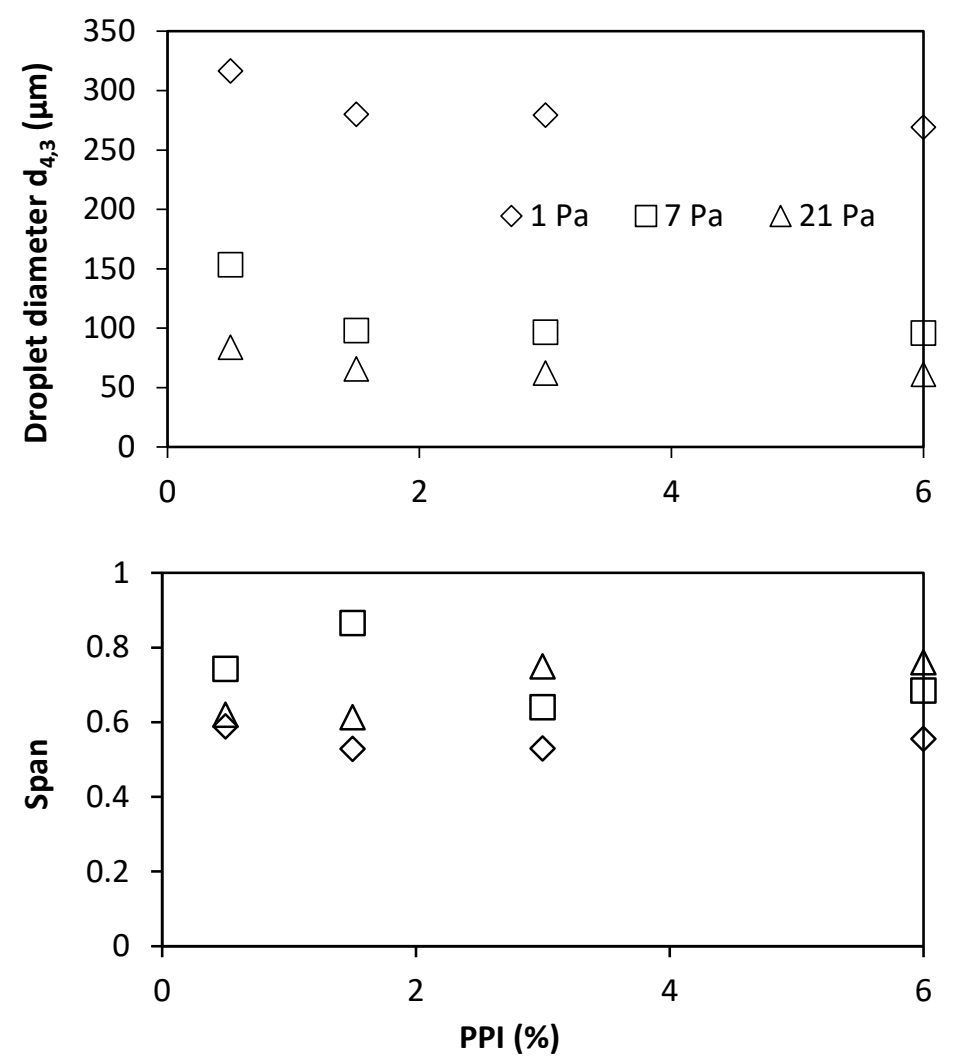

53

Figure 1: Effect of emulsifier concentration of A) Tween 20 B) OSA starch C) PPI to stabilise the w/o/w

55 emulsion assessed at three maximum shear stresses and at the injection rate of $1 \mathrm{ml} / \mathrm{min}$ on the droplet

56 size $\left(d_{4,3}\right)$ and span. Single experiments were carried out. 
$1 \mathrm{ml} \mathrm{min}{ }^{-1} \quad 3 \mathrm{ml} \mathrm{min}^{-1} \quad 5 \mathrm{ml} \mathrm{min}^{-1} \quad 10 \mathrm{ml} \mathrm{min}^{-1} \quad 15 \mathrm{ml} \mathrm{min}^{-1}$

60

61

62

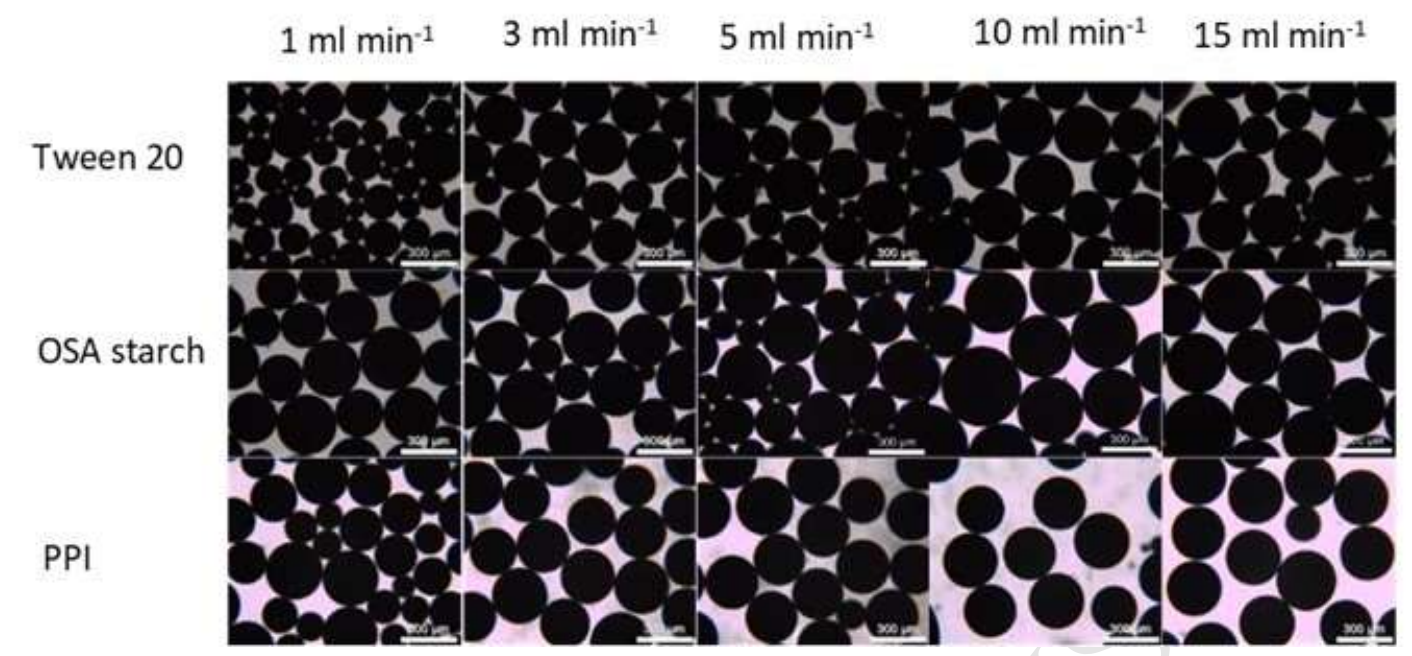

B)

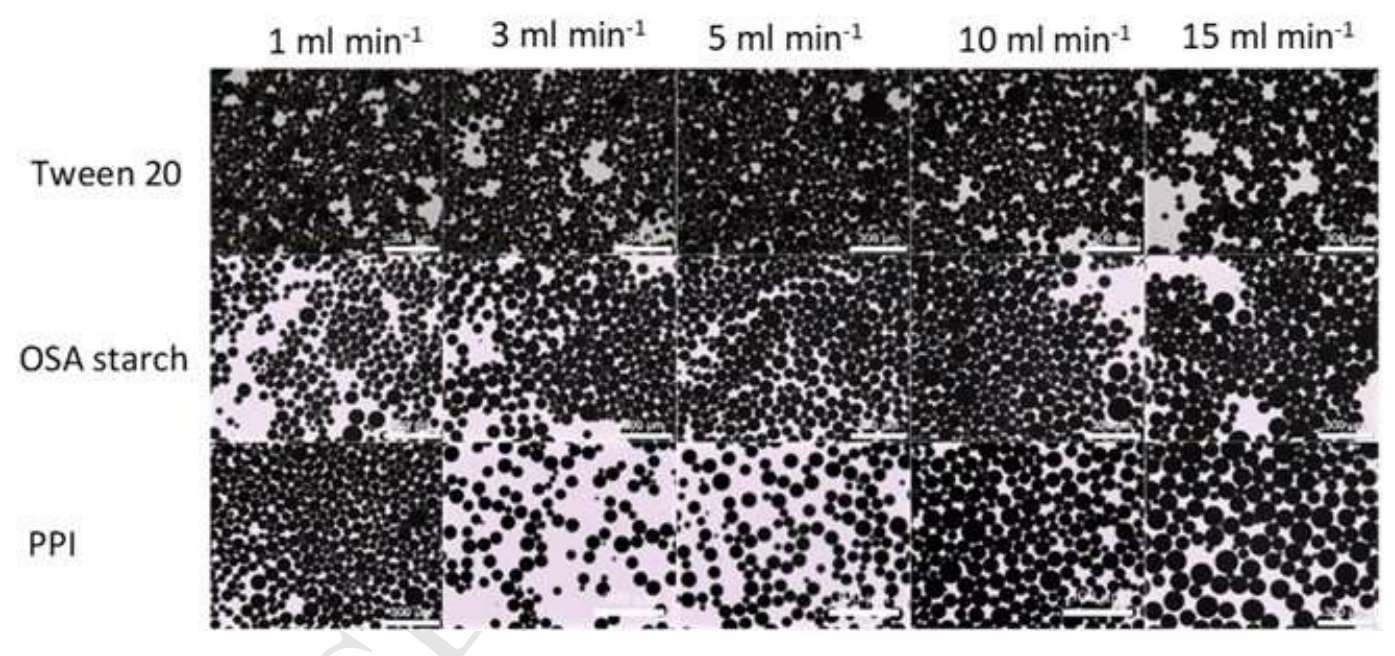

63

64

65

66

67

Figure 2: Micrographs of Tween 20, OSA starch or PPI stabilised w/o/w emulsions through stirrer cell membrane emulsification under different injection rates $\left(1-15 \mathrm{ml} \mathrm{min}^{-1}\right)$ and $\left.\mathrm{A}\right)$ lowest (1 $\left.\mathrm{Pa}\right)$ or $\left.\mathrm{B}\right)$ highest maximum shear stress (Tween 20: 20 Pa. OSA starch: 51 Pa. PPI: $21 \mathrm{~Pa}$ ). The scale bar in each micrograph is $300 \mu \mathrm{m}$. 
70

A)

71
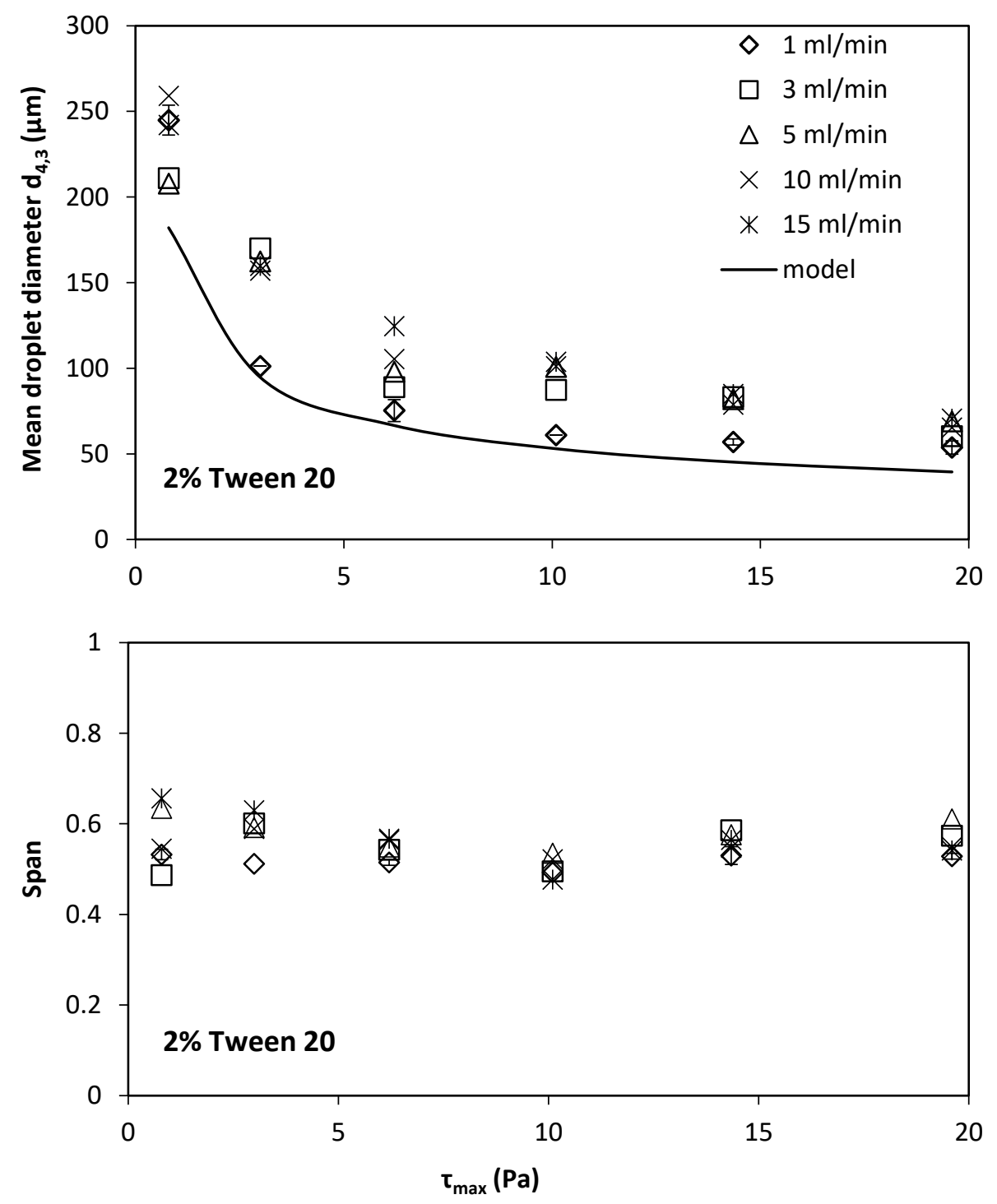

72

73

74 
$75 \quad$ B)

76
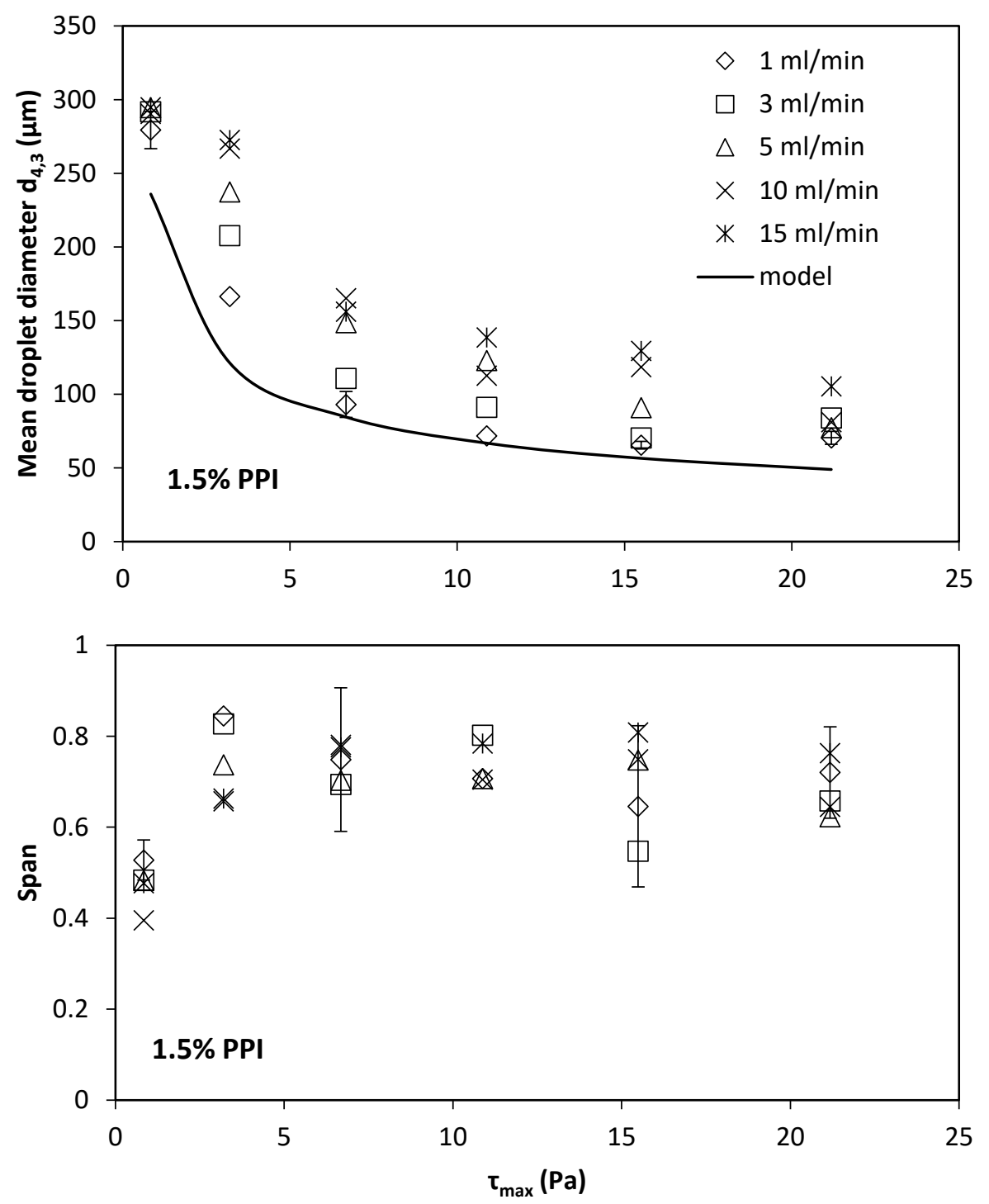

77

78 
79

C)

80
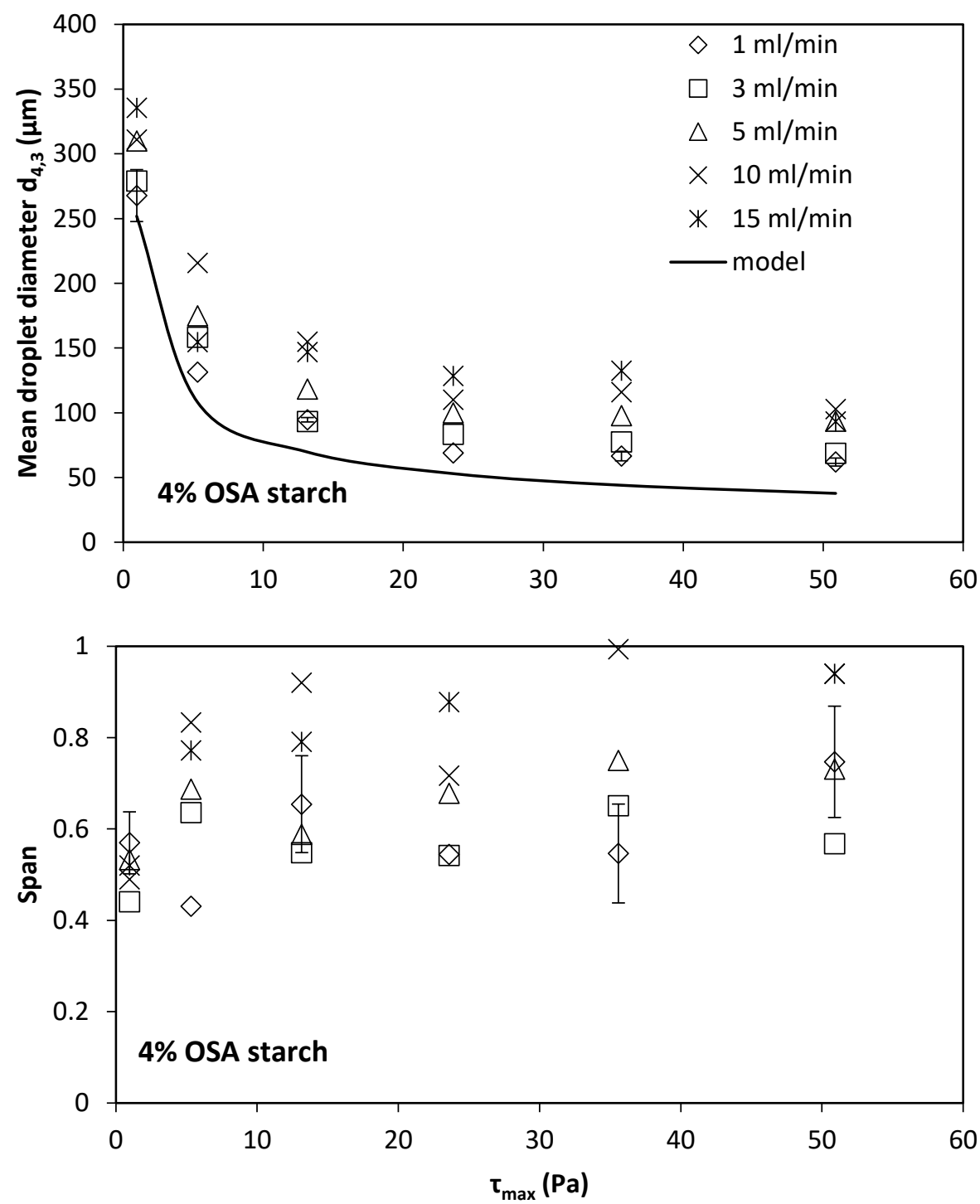

81

82 Figure 3: Effect of maximum shear stress $(1-51 \mathrm{~Pa})$ and injection rate $\left(1-15 \mathrm{ml} \mathrm{min}{ }^{-1}\right)$ on mean droplet

83 diameter $\left(d_{4,3}\right)$ and span of w/o/w emulsions stabilised with A) $2 \%$ Tween $\left.20, B\right) 1.5 \%$ PPI or C) $4 \%$ OSA

84 starch obtained experimentally and as predicted by the published model for comparison.

85 
A)

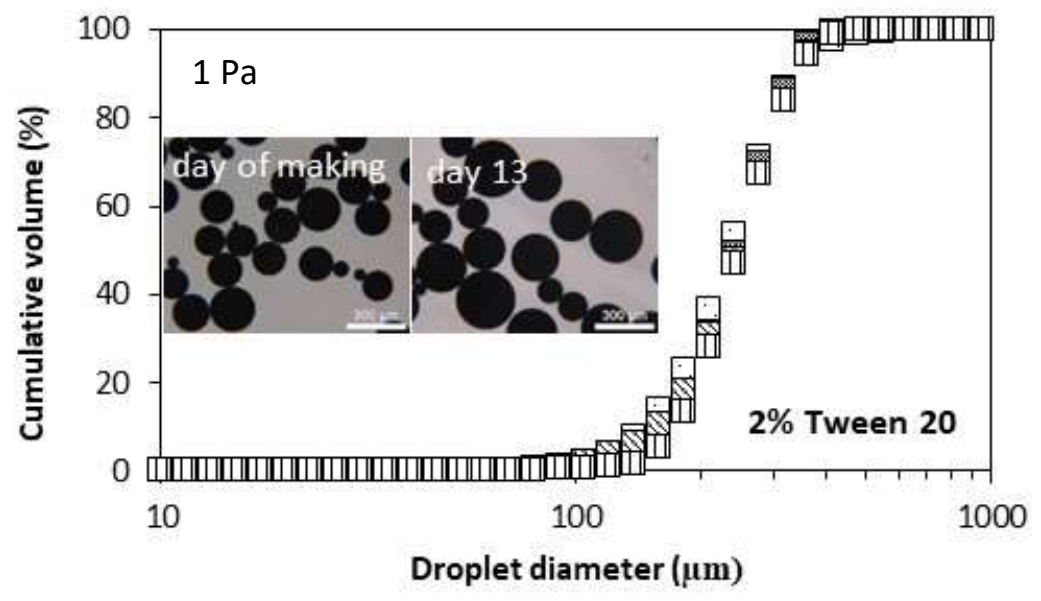

87

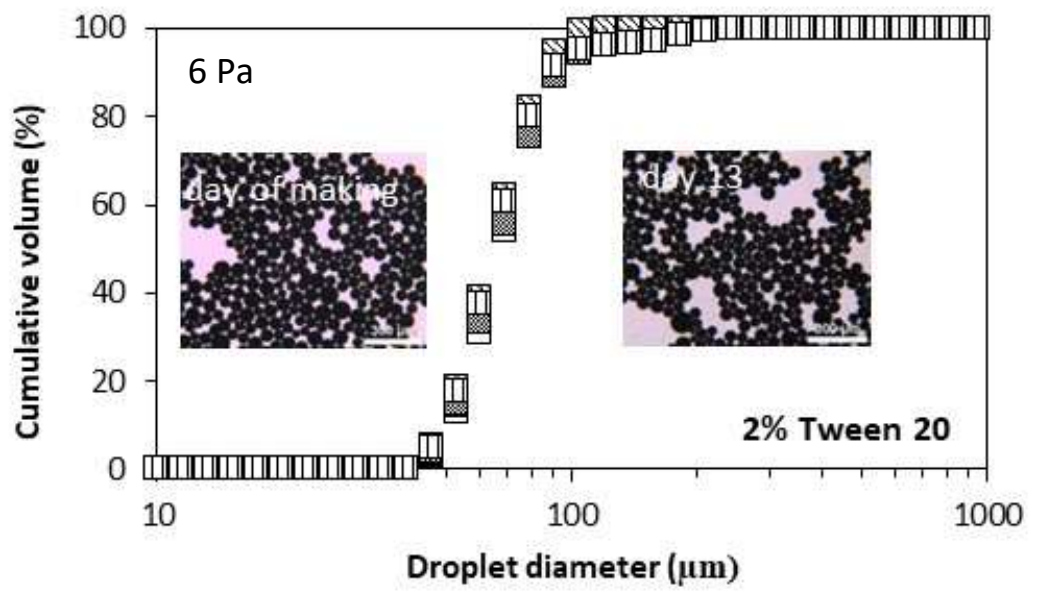

88

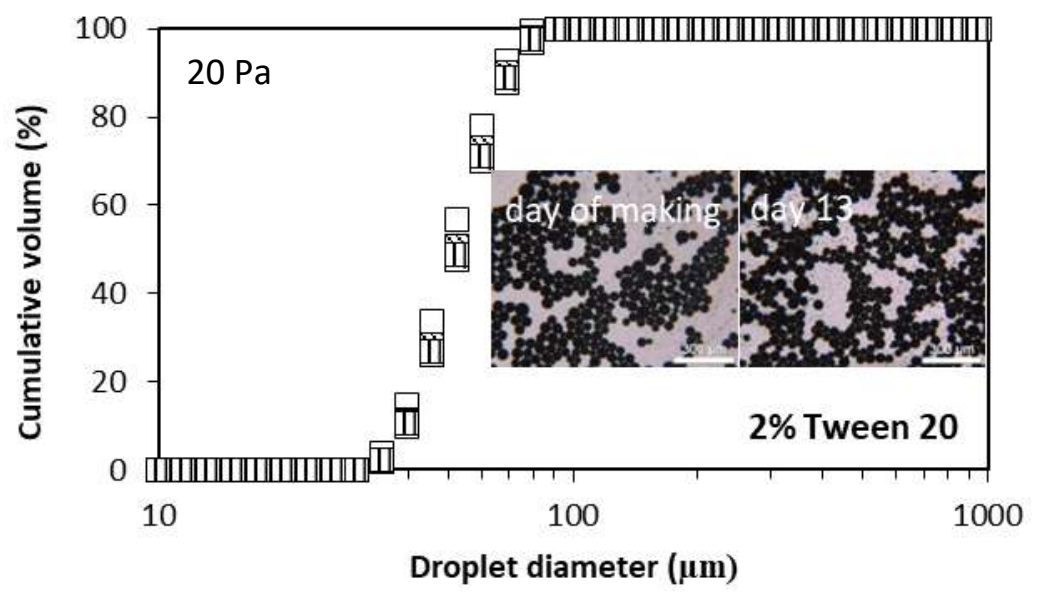

89

90 
$91 \quad B)$

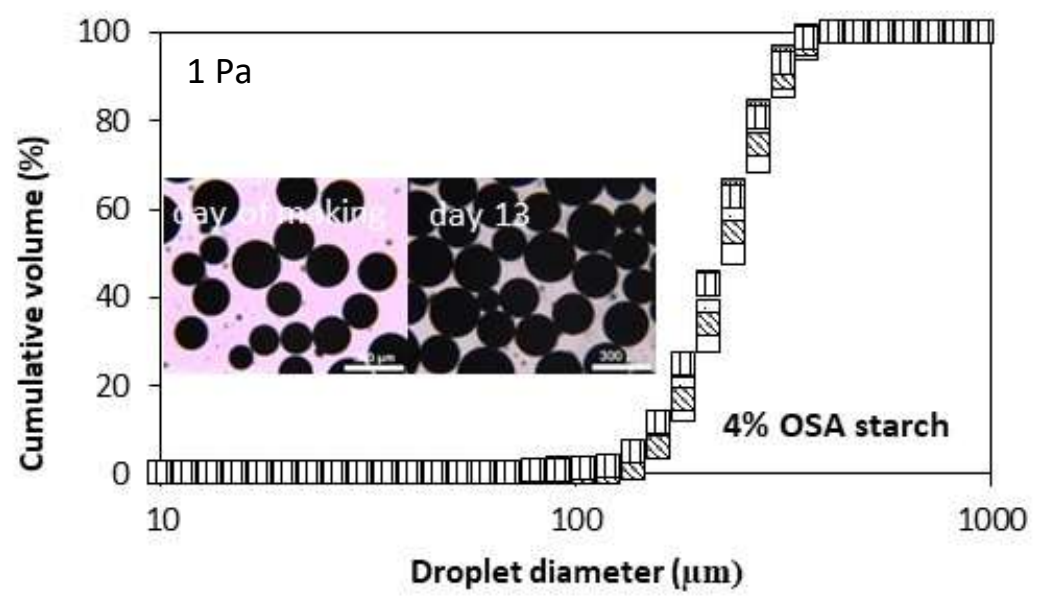

92

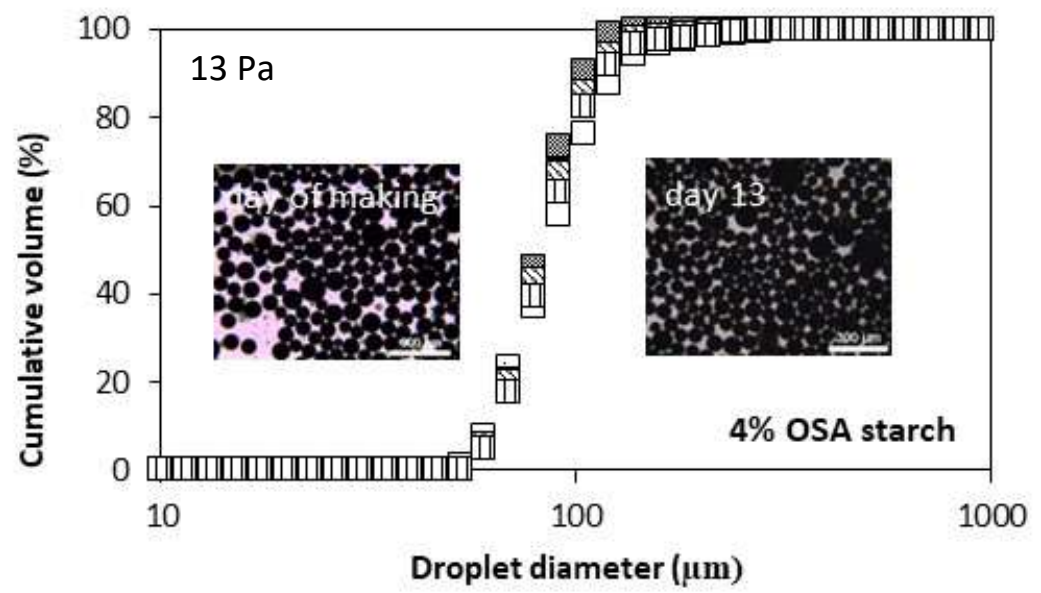

93

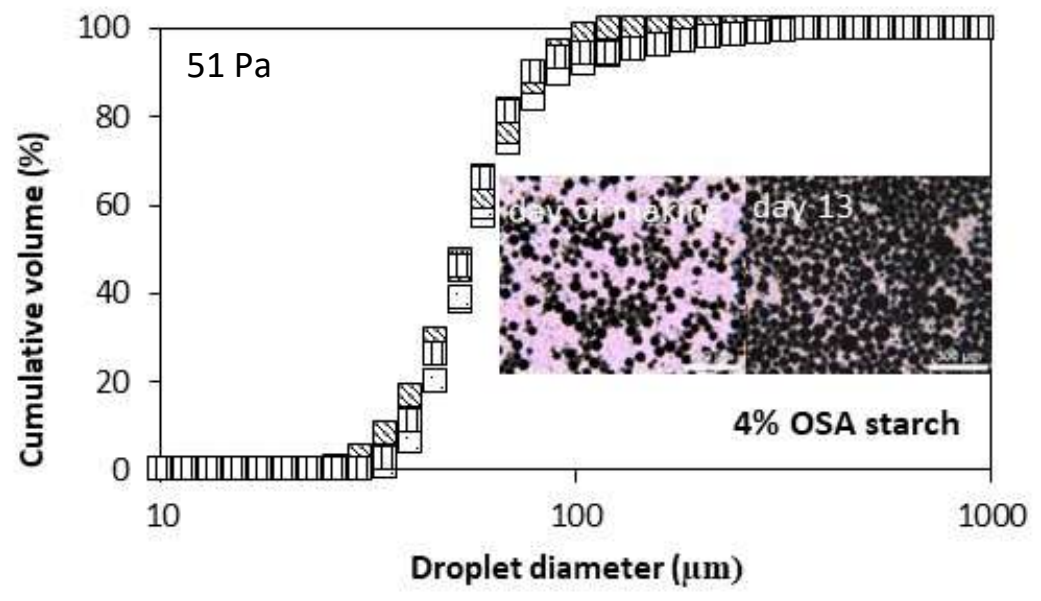

94

95 
C)

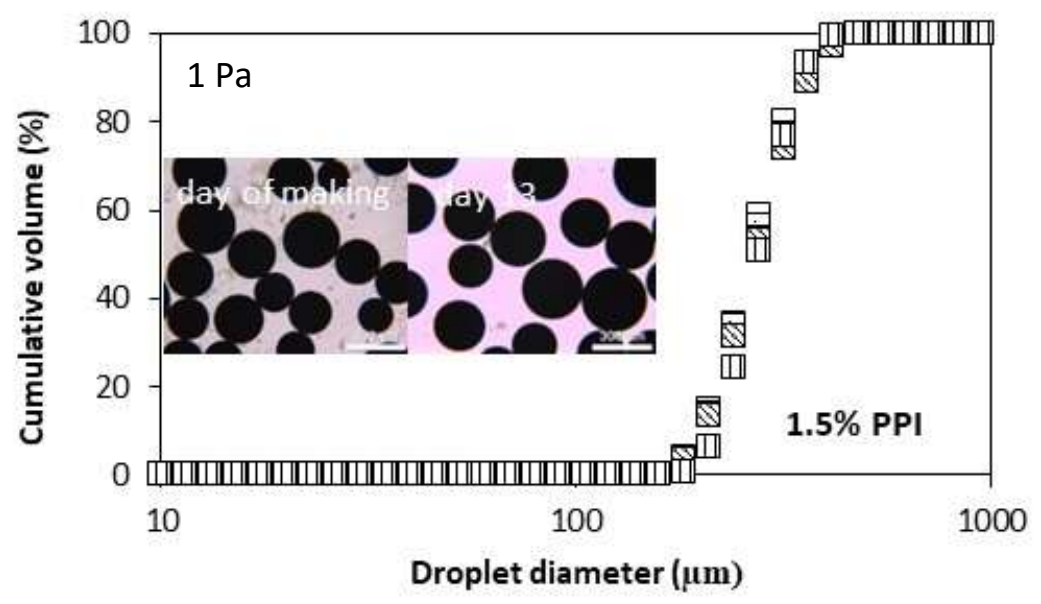

97

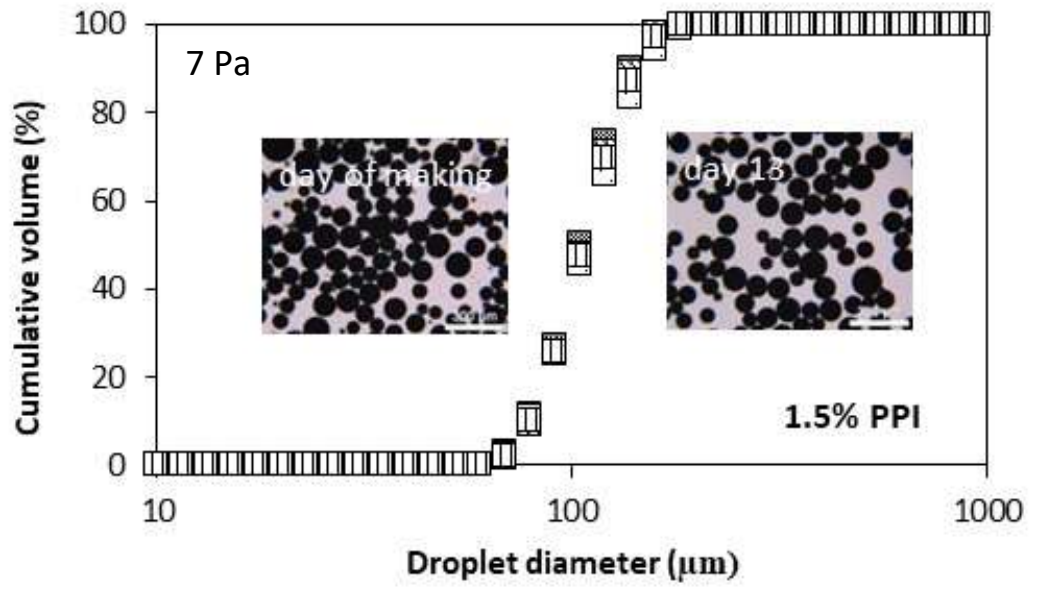

98

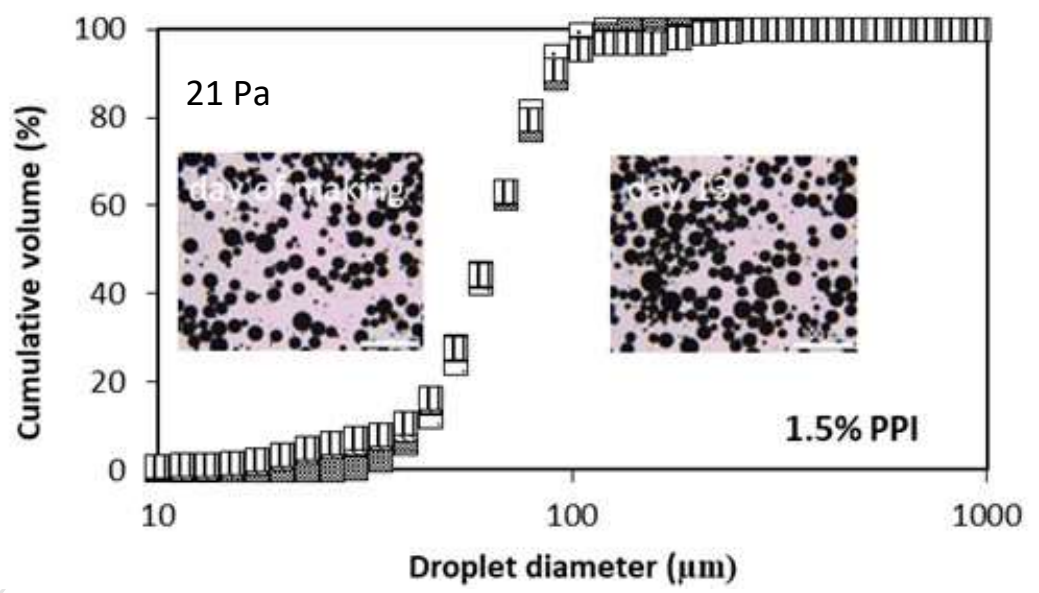

Figure 4: Droplet size distributions of w/o/w emulsions stabilised with A) 2\% Tween 20 B) 4\% OSA starch

101 or C) $1.5 \%$ PPI at different maximum shear stress.

102 Days: $\square$ day 0 (day of making), $\square$ day 1 , 圆day 2, , day $6 \square$ day 13 . The scale bar in each micrograph is $103300 \mu \mathrm{m}$. 
104

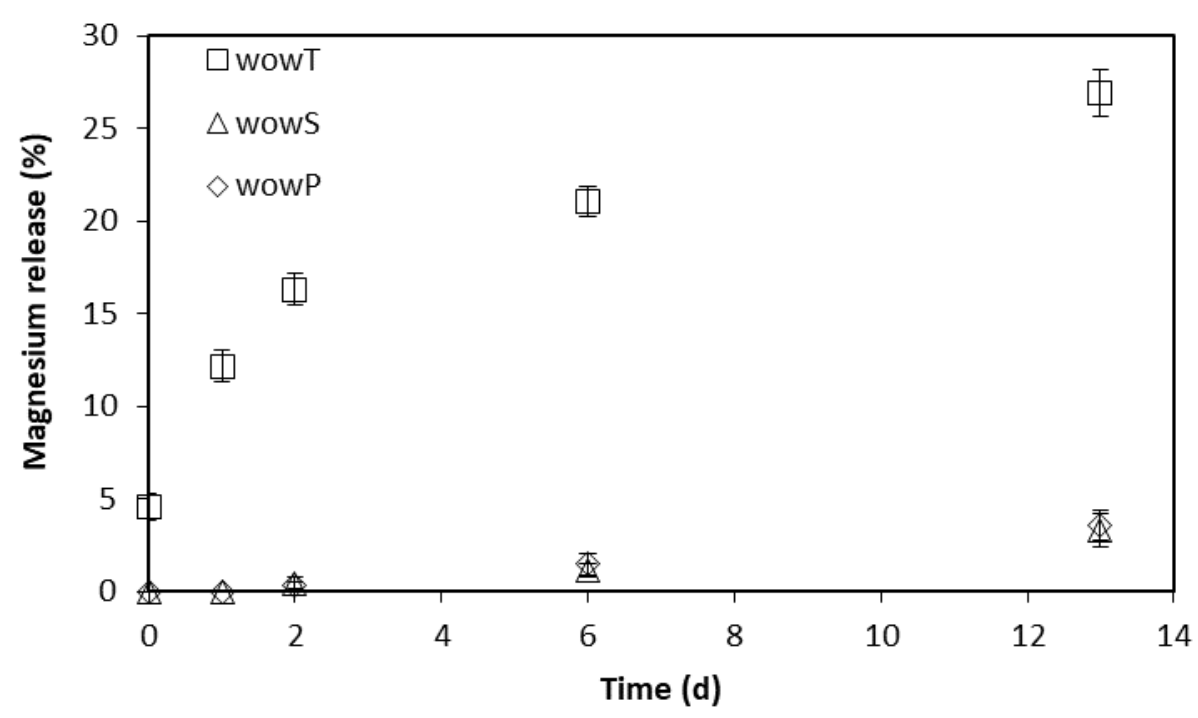

105

106 Figure 5: Magnesium release (Eq.3) from $w_{1}$ to $w_{2}$ of $w_{1} / o / w_{2}$ emulsions

107 


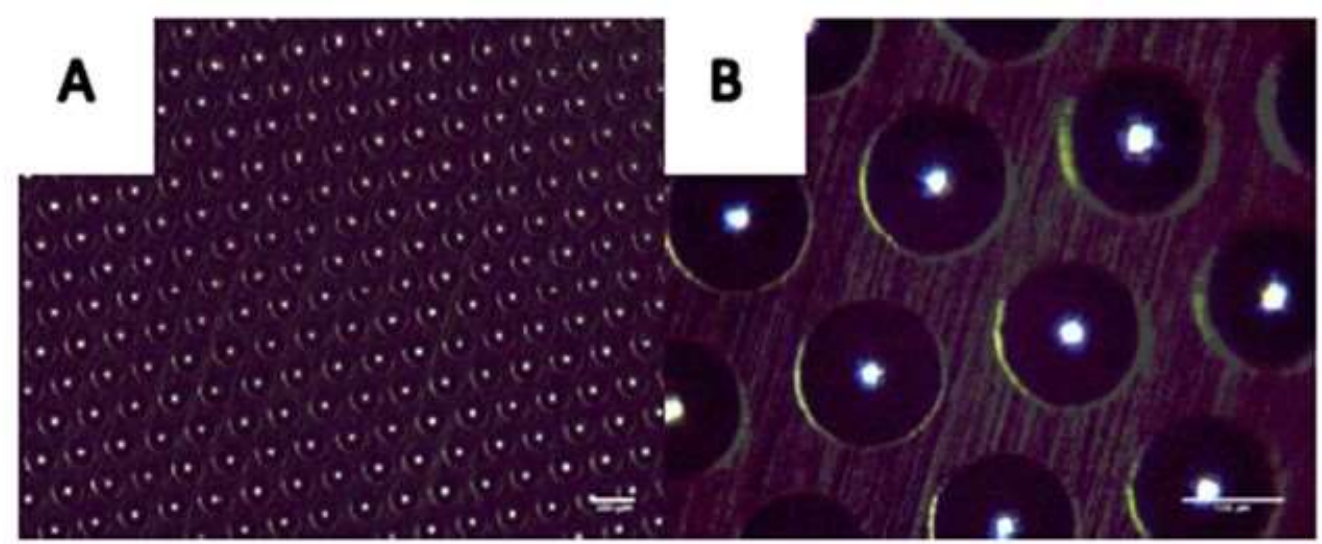

109

110 Figure A1: Micrographs of the membrane with a pore diameter of $20 \mu \mathrm{m}$ and a pore spacing of $200 \mu \mathrm{m}$.

111 The scale bar in A and B represents $200 \mu \mathrm{m}$ and $100 \mu \mathrm{m}$ respectively. 


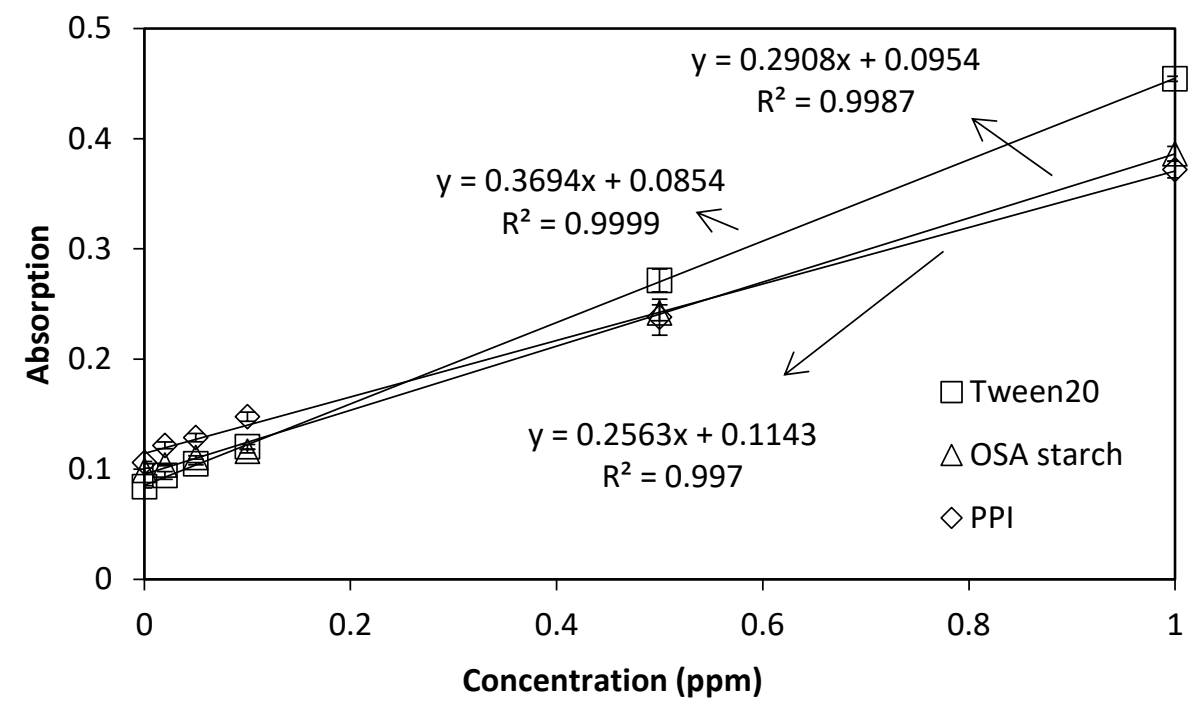

114 Figure A2: Standard calibration curves for $\mathrm{Mg}^{2+}$ in standard solutions: $2 \%$ Tween20, 4\% OSA starch or 1.5\%

115 PPI. All solutions contained 0.5\% Xanthan Gum to prevent creaming. 